\title{
Late Cretaceous environments and communities as recorded at Chrtníky (Bohemian Cretaceous Basin, Czech Republic)
}

\author{
JIŘí ŽíTT, RADEK VODRÁŽKA, LENKA HRADECKÁ, MARCELA SVOBODOVÁ \& KAMIL ZÁGORŠEK
}

\begin{abstract}
Five sedimentation episodes ranging from Upper Cenomanian to Lower Turonian (Korycany Member of the Peruc-Korycany Formation and Bílá Hora Formation) are documented from new outcrops at the Chrtníky quarry, Bohemian Cretaceous Basin (BCB). The first episode belongs to the lower Metoicoceras geslinianum Zone and is recorded only as phosphatic intraclasts in younger beds. The second and third episodes (upper M. geslinianum Zone) are represented by coarse conglomerates separated by an interval of condensed sedimentation, phosphogenesis, and erosion of incompletely lithified deposits. The third sedimentation episode is cut by erosion. Probably after a stratigraphic gap, a fourth episode followed and included further shaping of the underlying erosion surface (formation of a hardground s. lat.), stromatolite growth and phosphogenesis (second interval of condensed sedimentation), corrosion and redeposition of diabase clasts, calcareous mud deposition and firmground formation, and, finally, deposition of dark claystone and burrowing. This succession seems to be of Early Turonian age, Whiteinella archaeocretacea (?) Zone. Basal portions of the fifth sedimentation episode (Lower Turonian, Helvetoglobotruncana helvetica Zone) started after the erosion event and included marly deposits rich in macrofauna, whereas the overlying strata yield an impoverished fauna predominated by sponges. In the topmost part of the succession, fully oxic conditions with abundant macrofauna are documented. The biostratigraphic conclusions are based on macrofauna and micropalaeontology (palynomorphs and foraminifera), and on correlations with other shallow-water successions (Předboj, Velim, Pecínov). Finds of enormously abundant remains of the crinoid Cyathidium aff. depressum (Sieverts) are unique. Common bryozoan and microfossil associations document a deepening of the basin during the fifth sedimentation episode. An identical development is documented by gradual changes in ecologic types of sponges (Pachytilodia bohemica $\rightarrow$ Chonella-Verruculina-Siphonia $\rightarrow$ Laocoetis-Guettardiscyphia-Diplodictyon assemblages). The taphonomy of macrofauna supports previous views of the geological and sedimentological developments in the area. Nontronite, which causes the greenish colour of clay laminae mainly in stromatolites, was identified for the first time in the BCB. - Key words: Bohemian Cretaceous Basin, Upper Cenomanian-Lower Turonian, taphonomy, palaeoecology, sedimentary environment.
\end{abstract}

ŽíTt, J., VODRÁŽKA, R., HRADECKÁ, L., SVOBODOVÁ, M. \& ZÁGORŠEK, K. 2006. Late Cretaceous environments and communities as recorded at Chrtníky (Bohemian Cretaceous Basin, Czech Republic). Bulletin of Geosciences 81(1), 43-79 (22 figures, 3 tables). Czech Geological Survey, Prague. ISSN 1214-1119. Typescript received October 3, 2005; accepted in revised form January 12, 2006; issued March 31, 2006.

\begin{abstract}
Jiři Žitt, Academy of Sciences of the Czech Republic, Institute of Geology, Rozvojová 135, 16502 Praha 6; zitt@gli.cas.cz•Radek Vodrážka, Czech Geological Survey, Klárov 3/131, 11821 Praha 2; Charles University, Faculty of Science, Institute of Geology and Paleontology, Albertov 6, 12843 Praha 2; vodrazka@cgu.cz・Lenka Hradecká, Czech Geological Survey, Klárov 3/131, 11821 Praha 2; hradecka@cgu.cz・Marcela Svobodová, Academy of Sciences of the Czech Republic, Institute of Geology, Rozvojová 135, 16502 Praha 6; svobodova@gli.cas.cz・Kamil Zágoršek, National Museum, Václavské náměstí 68, 11579 Praha 1; kamil.zagorsek@nm.cz
\end{abstract}

The first modern study of the Chrtníky locality (Žitt \& Nekvasilová 1991) was aimed at new finds of Late Cretaceous cementing epifaunas of the hard diabase substrates. Previous studies by Zázvorka (1946) and Tichý (1968) were also greatly supplemented by this later work. The taxonomy of part of the macrofauna has been discussed by Nekvasilová (1973, 1986; brachiopods), Vodrážka (2005; sponges), Ziegler (1984; worms), Záruba (1965a, b; oysters), and Žitt (2004, 2005; asteroids). Studies at the Chrtníky quarry continued in the mid 1990s, and all new outcrops and faunas were carefully documented (mainly by R. Vodrážka). Brief data were published by Vlačiha (2002), and preliminary results summarized by Žítt et al. (2004). The present outcrops at Chrtníky offer opportu- 

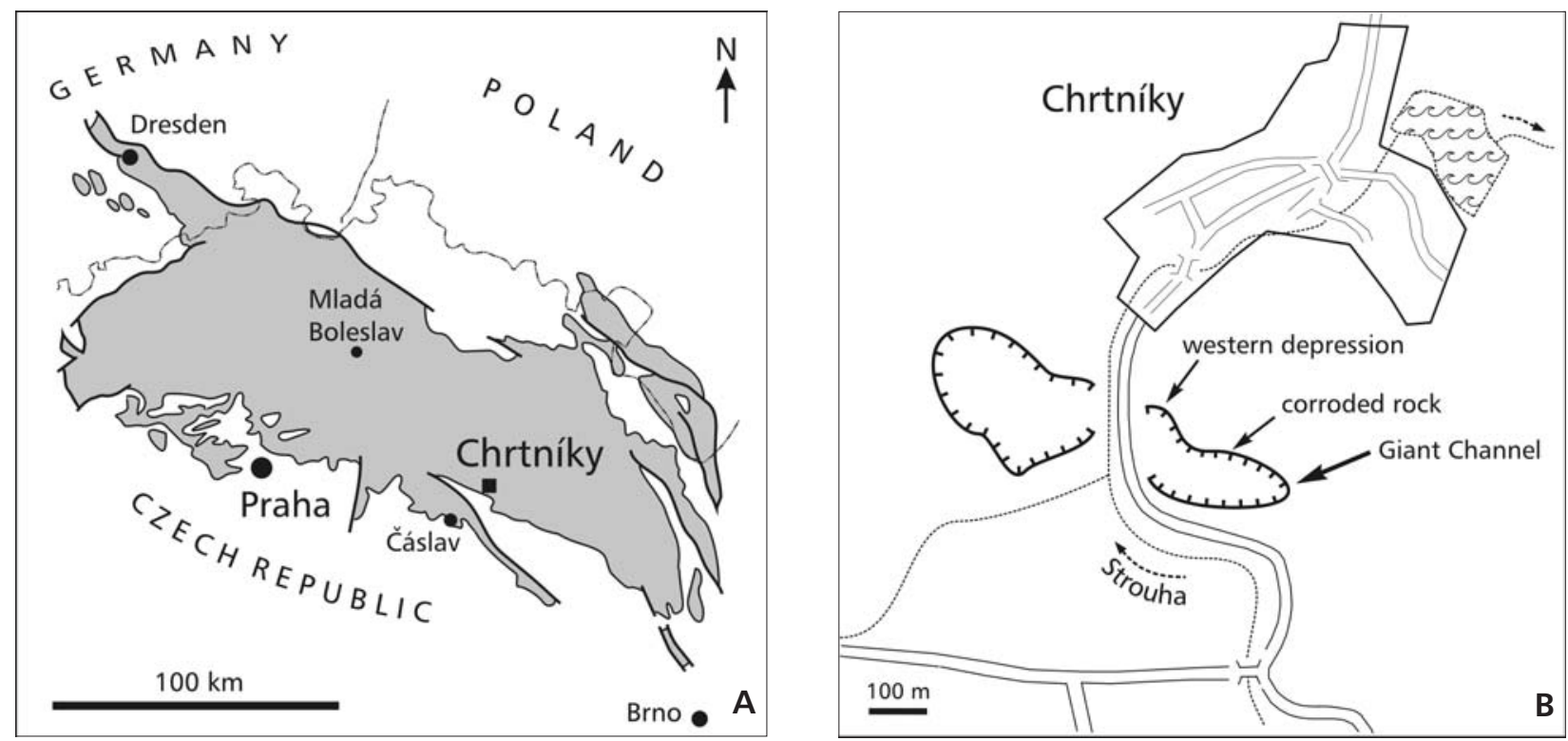

Figure 1. Sketch maps with the location of Chrtníky in the Bohemian Cretaceous Basin (A), and the location of the quarry (B).

nities for the continuation of more detailed studies of all phenomena connected in any way with the shallow-water Late Cenomanian-Early Turonian sedimentation and biota. Particular sedimentological and palaeontological features of the strata are preserved mostly in depressions of the former rocky coast and upper shoreface. These sea floor zones were studied many times before at several other Bohemian localities (e.g., Žítt et al. 1997, 1999, 2001, 2002a, b). However, new studies at Chrtníky confirm that each locality of this type is unique and may supply data of general importance.

The quarry wall exposing the former site (Žítt \& Nekvasilová 1991) has presently shifted several tens of metres eastwards, and the Cretaceous fill of an exceptionally deep, rocky bottom channel was cut across its entire depth. New outcrops also came into existence along the northern quarry wall. Careful collections of macrofauna were assembled by R. Vodrážka both in the field and by screen washing large quantities of sediment $(>500 \mathrm{~kg})$. The sedimentological study was in part based on polished sections. Micropalaeontological (palynomorphs, foraminifera) investigations were carried out for the first time.

The material studied, mainly the fossils, rock samples and sections, and foraminiferal samples, are kept in the Institute of Geology ASCR (Academy of Sciences of the Czech Republic) in Prague, and in the private collections of R. Vodrážka and J. Žitt together with the most important washing residues. After the studies are completed, all documented material will be deposited in the National $\mathrm{Mu}-$ seum, Prague. Chemically processed palynological preparations are curated by M. Svobodová at the Institute of Geology, Prague.

\section{Geographical and geological settings}

The area of Chrtníky is situated in the northeastern part of the Železné hory Mts., Pardubice district, eastern Bohemia. Upper Cretaceous sediments crop out in the large working diabase quarry situated on Mezihoří Hill (297 metres above sea level) east of the Strouha Brook, about $5 \mathrm{~km}$ northwest of Heřmanův Městec (Fig. 1). The diabase massif is of Early Palaeozoic age. The quarry walls cut into shallow to very deep sea erosional depressions in the diabase bedrock and their Cretaceous fills. Diabase conglomerates prevail in the basal parts of the majority of depressions, and are overlain by limestones to marlstones, on which follow siltstones. The geological history is rather complex, with records of five sedimentation episodes (discussed below). The sediments belong to the Korycany Member of the Peruc-Korycany Formation and to the overlying Bílá Hora Formation (sensu Čech et al. 1980). Two intervals of condensed sedimentation have also been recognized.

The Upper Cretaceous (Upper Cenomanian-Lower Turonian) strata are best exposed in the deepest depression (here named the 'Giant Channel') situated in the eastern part of the quarry, though interesting phenomena also occur in the median and western parts of northern quarry wall (Fig. 1).

\section{Giant Channel}

\section{General features}

Position. - The Giant Channel (GC) is situated in the easternmost part of the quarry and is cut by a short eastern wall at two quarry levels (Figs 1,2). 
Shape, size, direction. - The cross section documented during quarrying (1999-2005) is sharply trough shaped (Fig. 2), and the channel as a whole generally dips to the east. The studied section (2005) shows an overall GC depth of about 17 metres, although the topmost 2.5 metres of Cretaceous fill were destroyed and replaced by Quaternary loess (Fig. 3). Where visible, the walls of the GC are strongly abraded and show moderately rounded elevations cut by the quarry wall (Fig. 6). Undoubtedly, the GC came into existence in a part of the diabase rock predisposed by tectonics and pre-transgression weathering. So far, the Giant Channel at Chrtníky represents the deepest, largest, and best exposed outcrop of this type over the entire Bohemian Cretaceous Basin. For instance, the couple of channels exposed at Velim (channels called Václav and Veronika) reach about 10-11 metres in depth (Žítt et al. 1997), and the visible part of a depression at Kuchyňka near Brázdim was 7 metres deep (Žítt et al. 2002b).

Cretaceous sedimentary fill of GC is rather complex and is here divided into 8 units. Numbers of units and beds appear in the geological section (Fig. 3).

\section{Unit 1. Lower conglomerate}

Position. - This conglomerate fills the lower part of the GC up to a thickness of about 12-13 metres (see also Fig. 2), as high as the horizon of the first condensation interval (see below), roughly coinciding with the base of the upper quarry level.

Lithologic character. - The conglomerate is coarse and unsorted. The structure is boulder- and large-pebble-supported, with local irregular clast- or matrix-supported streaks of better-sorted material containing mostly smaller clasts (cobbles and small pebbles). The petrographic composition of the rock clasts is mostly diabase, and is identical with the surrounding rock into which the GC eroded. Grey granitoid clasts (probably derived from younger veins) are very rare (Fig. 5A). The common boulder size is around one metre, though some exceed 3 metres. All clasts, regardless of their size, are strongly abraded and rounded. Only the largest boulders tend to be suboval to subangular, showing the shapes of the original diabase fragments from which the rounded clasts were derived. The lithology of the conglomerate matrix varies strongly both horizontally and vertically. It is prevailingly sandy in the lower conglomerate part, and is of variegated colour (yellowish, greenish, rarely reddish), mostly massive and hard (Fig. 5A), though loose in places, and formed of sand. In harder parts the colour used to be whitish due to the presence of carbonate. The matrix of the upper conglomerate part (about the topmost $50 \mathrm{~cm}$ ) is extremely variable, mostly greenish and reddish, irregularly carbonate with frequent sparitization.

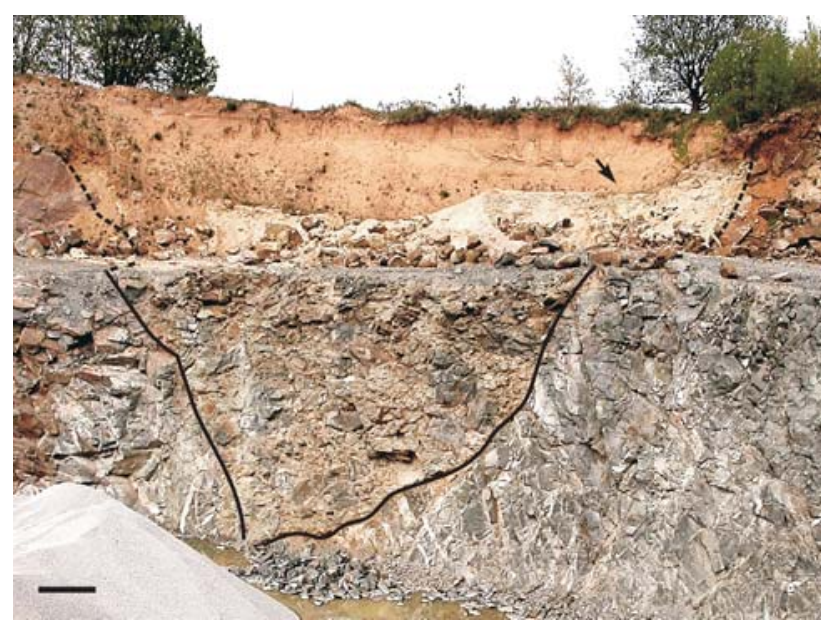

Figure 2. Chrtníky, eastern part of the quarry. The Giant Channel cuts across two quarry levels. Black scale bar $=2 \mathrm{~m}$, arrow - a part of section illustrated in Fig. 6.

The topmost several centimetres are dark grey, nearly black when wet, formed of soft sandstone to siltstone or, locally, of sandy limestone (Fig. 3D). The conglomerate is bounded on top by deposits of condensed sedimentation (see below).

Macrofaunal features. - Samples of the macrofauna were collected by washing the sandy, loose matrix of the basal conglomerate parts. Fragments of undeterminable bivalves, up to $10 \mathrm{~mm}$ large, prevail. They are abraded and angular, and often show signs of partial dissolution. The only complete organic remains are those of the brachiopod $G i$ silina? rudolphi (Geinitz) (Fig. 4A). Short fragments of spines of Tylocidaris vesiculosa (Goldfuss) and isolated valves of an indeterminate oyster (Gen. et sp. indet.; Fig. 4B) were also found. In the more massive limestone matrix of the median conglomerate portions there occur large oysters, probably Ostrea cf. operculata Reuss and Rastellum diluvianum (Linné). Their invariably disarticulated valves are fragmented or complete, and often found in clusters. Serpulid worms densely encrusting a boulder were also found in the middle part of the conglomerate, together with an indeterminate brachiopod valve and many variously abraded fragments of molluscs. In the topmost grey matrix, isolated elements of the crinoid Isocrinus sp. appear. The bivalve (mainly oyster) remains are usually partly silicified throughout the conglomerate.

\section{Unit 2. Lower condensation interval}

Position. - Deposits of this interval overlie the lower conglomerate accumulation (unit 1) and are about 5-15 cm thick (Fig. 3D). They are rarely exposed (mostly hidden below the rock debris) along the base of the upper quarry level (Fig. 2). 

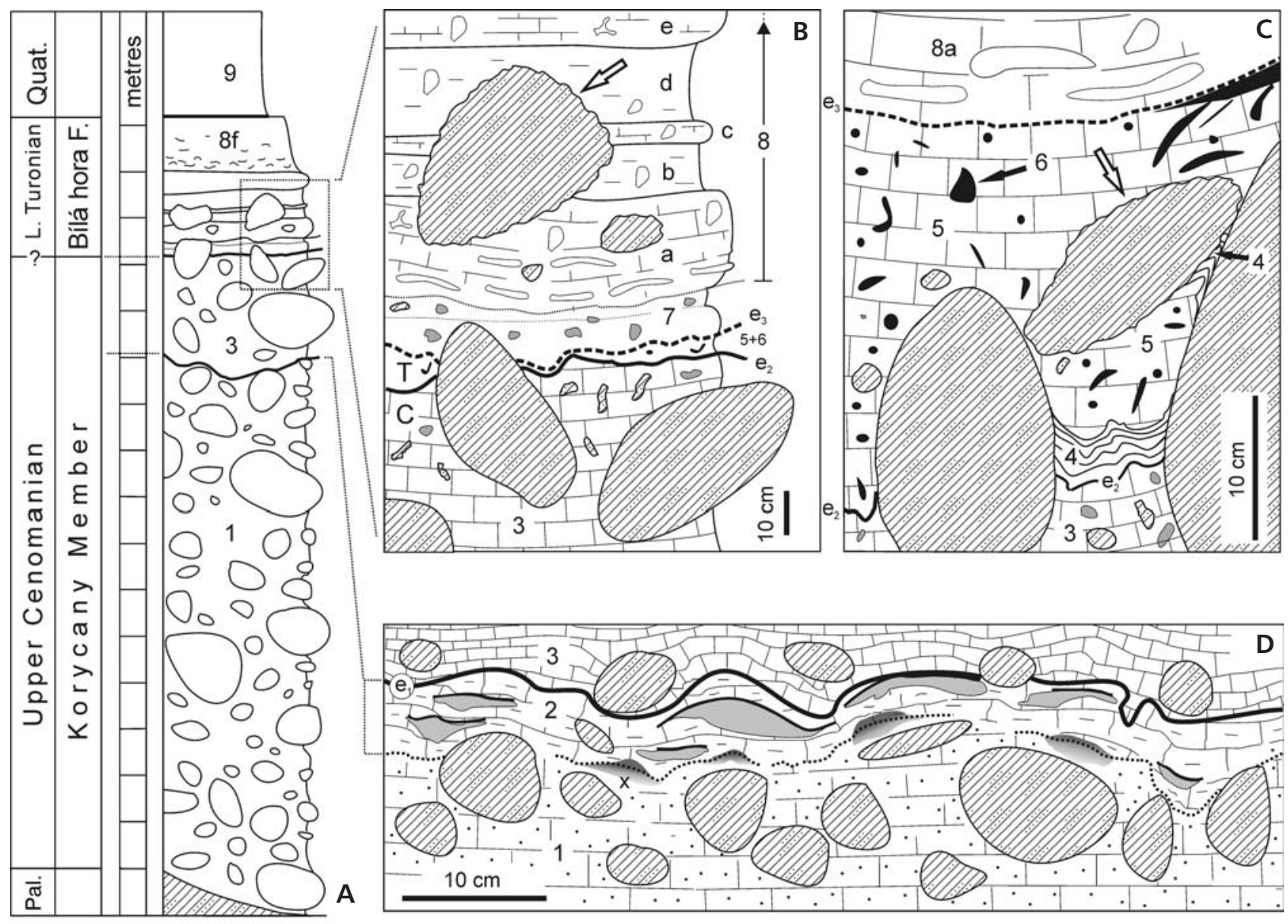

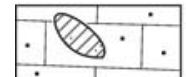

a

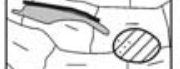

b

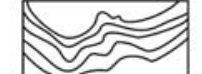

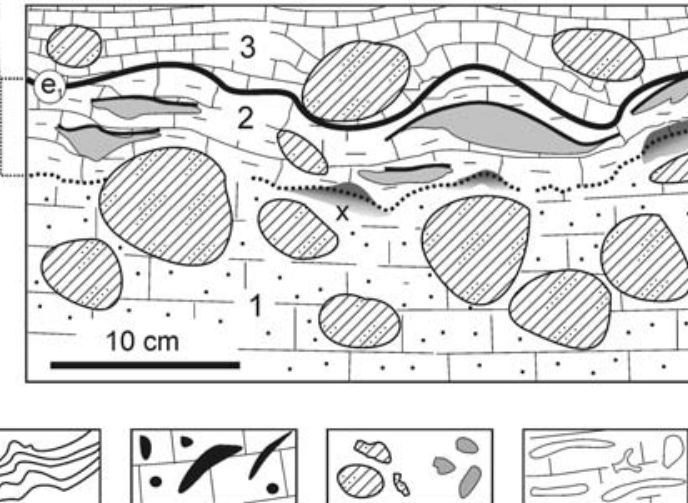

d

e

f

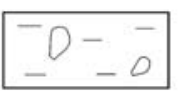

g
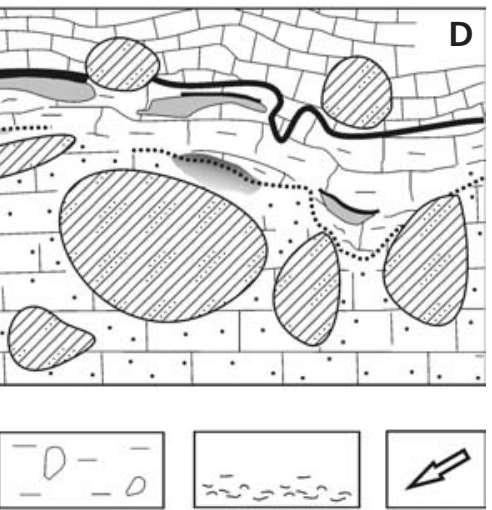

$\mathrm{h}$

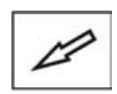

Figure 3. Chrtníky. Giant Channel, lithology and development. $\bullet$ A - complete section in 2000 . B - close-up view of A. $\bullet$ C - detailed structure of interstitial fill between erosion surfaces $\mathrm{e}_{2}$ and $\mathrm{e}_{3}$, with stromatolite and burrowed horizon situated lateral to the section in Fig. 3B (studied in 2004-2005). • D - close-up view of the lower erosion surface $\left(\mathrm{e}_{1}\right)$ and adjacent deposits. 1-8 - numbering of Cretaceous sedimentary units and beds (see descriptions in text). $x$ (in Fig. 3D) - approximate boundary between units 1 and 2 (dotted line), crossed by local phosphatization. Legend: a - sandy limestone with diabase clasts, $\mathrm{b}$ - limestone with diabase clasts and phosphates (grey) capped by green nontronite coatings (solid line) - the structures were probably deformed by the pressure of overlying sediment, $\mathrm{c}$ - stromatolitic buildups (unit 4), d-limestone with burrows (units 5,6 ), e - designation of oval and subangular diabase clasts (left) and phosphatic intraclasts (grey, on the right) as used at Figs 3B and C, f - compact calcareous siltstone with prevalent sponges, $\mathrm{g}$ - soft siltstone with sponges, $\mathrm{h}$ - clayey siltstone with abundant fauna, $\mathrm{i}$ - empty arrow (used at Figs $3 \mathrm{~B}$ and $\mathrm{C}$ ) marking the diabase clast with corroded surface. Pal. means Palaeozoic rocks.

Lithologic character. - The dark matrix of the lower conglomerate (unit 1) seems to be indistinctly winnowed, and is raised in islets up to $10 \mathrm{~cm}$ in size by newly transported, several centimetre-thick, silty sediment that was later phosphatized. These phosphatized islets seem to have originally formed an irregular, low, wavy relief on the bottom (at least partly between large clasts). The phosphatization penetrates down to the dark matrix as deep as $1 \mathrm{~cm}$, but becomes weaker below that depth (Fig. 3D). The phosphate is of a light brownish to beige colour. The entire surface, both on islets and between them, is overlain by grey massive clayey limestone in which other phosphatized islets are ar- ranged in 1 or 2 levels. The phosphatization of islets was terminated by the precipitation of very thin phosphatic laminae on their upper surfaces. The upper surfaces of all phosphatic deposits are covered by thin ( $1 \mathrm{~mm}$ maximum) coatings of a green claystone identical to that of the upper condensed interval (see below; unit 4). A very thin green film may locally pass from the phosphatic islets onto the surrounding limestone. The top surface of limestone with islets is erosional and consists of specific shapes. The limestone of the overlying unit 3 (see below) covers this entire surface and penetrates irregularly and deeply beneath small diabase clasts and large bioclasts, sometimes as deep 
as the surface of the dark matrix of underlying conglomerate. This seems to indicate a low degree of lithification in the sediments of the condensation interval (Figs 4C, D).

Macrofaunal features. - The sediment of phosphatic islets contains abundant small (around 1-3 $\mathrm{mm}$ ) bioclasts, most of which are slightly abraded, but sometimes well preserved (indeterminate small disarticulated bivalve). Isolated valves of large indeterminate oysters - probably Ostrea cf. operculata and Rastellum diluvianum - are visible as cross sections in the grey massive limestone.

\section{Unit 3. Upper conglomerate}

Position. - The upper conglomerate follows upon deposits of the first condensation interval, and is about 2 metres thick (Fig. 3). This accumulation is cut by an erosion surface $\left(\mathrm{e}_{2}\right)$, and the true extent of sedimentation is not known.

Lithologic character. - The type of clasts in basal parts of this conglomerate is very similar to that of the lower conglomerate (unit 1), but the percentage of cobbles and pebbles decreases upwards as boulders prevail. The clasts are well rounded and often bear coatings of various colours, mostly reddish, brownish, and greenish, sometimes with dark reddish crusts $(\mathrm{Fe})$. In the top part, about $0.5-0.7 \mathrm{~m}$ below the upper erosion surface, the proportion of smaller diabase clasts (pebbles up to $30 \mathrm{~cm}$, but mainly small cobbles) increases. They are, however, mostly subangular to suboval, sometimes even sharp edged, frequently flat, irregularly shaped, and intensively coloured (dark to light green, red, brown to nearly black) (Fig. 5B). Thick Fe-rich crusts with botryoidal surface structures coat some of them. The conglomerate matrix is of massive hard limestone with a slight sand admixture. The quartz sand grains in the matrix are rounded and subangular. Glauconite grains are rare. The matrix is full of small bioclasts in the basal parts overlying the deposits of the first condensation interval (Fig. 4E). In the middle portions, very massive and hard limestone with rare bioclasts prevail (Fig. 5C). The limestone is mostly of reddish and, more rarely, greenish hue. The intensity of the reddish colour decreases slowly with distance from the clast surfaces. In the

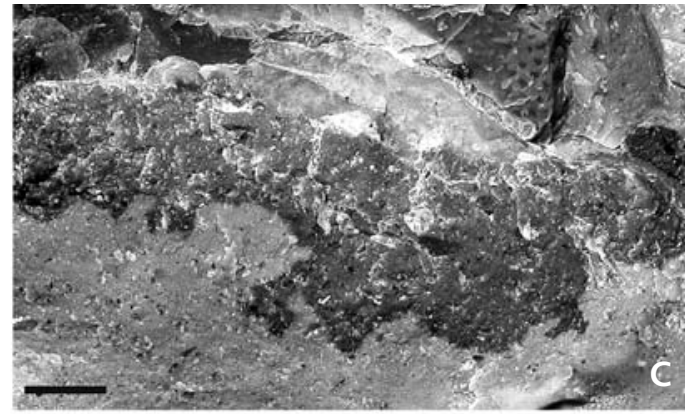

A

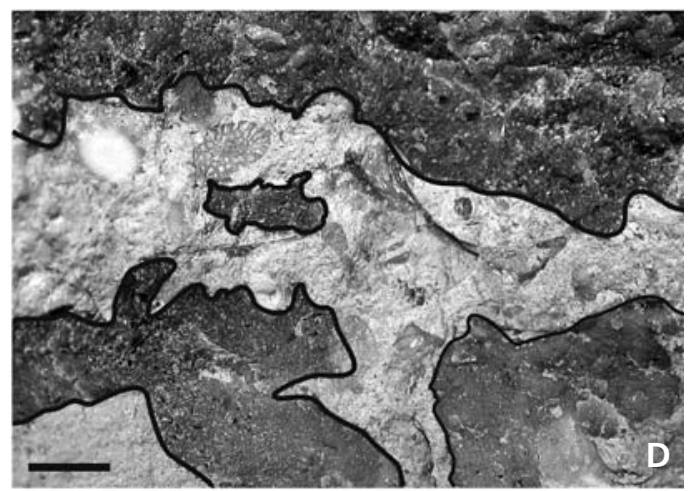

B

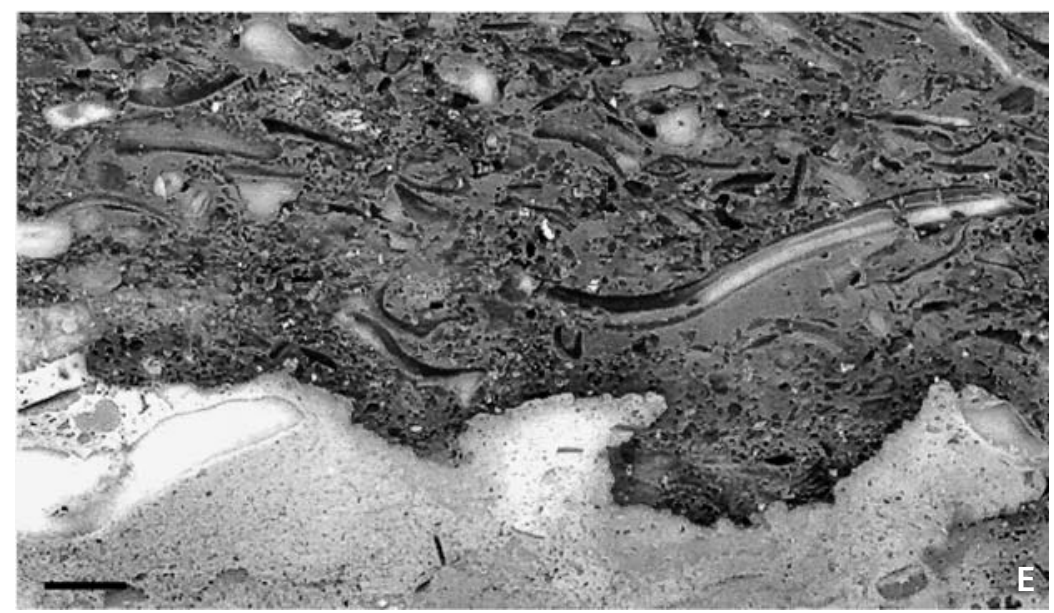

Figure 4. Representatives of the macrofauna from unit 1, near the base of the Giant Channel. -A - Gisilina? rudolphi. • B - indeterminate oyster (Gen. et sp. indet.), probably upper valve. • $\mathrm{C}-\mathrm{E}$ - close-up views of erosion surface 1 between sediments of the lower condensation interval (unit 2) and unit 3 (matrix of conglomerate). Note the irregular shapes of the erosion surface and the portions of unit 3 (dark) penetrating the underlying unit 2 (solid black outlines in Fig. 4D). Scale bars: A, B $-1 \mathrm{~mm}, \mathrm{C}-\mathrm{E}-2 \mathrm{~mm}$.

top parts of conglomerate, where the small angular clasts increase in number, the limestone matrix gradually becomes more clayey and pink to whitish, light greyish, or light yellowish in colour (Fig. 5B). Small phosphatic intraclasts (mostly $<10 \mathrm{~mm}$ ) of various character abruptly appear here (see unit 7). Their concentration is highest near the erosion surface, but locally they are completely absent.

The clastic component (including boulders) is abundant even above the erosion surface, where the interstices provided niches for the formation and preservation of younger 
deposits. The proportion of smaller clasts decreases, and their abrasion resembles those below the erosion surface. The diabase clasts (mostly boulders) with completely different surface structures, formed by corrosion in the imme- diately overlying sediments, have a different origin and are discussed below (see unit 4 below).

Local concentrations of malachite, occurring as thin coatings on the limestone joints, are also of interest.
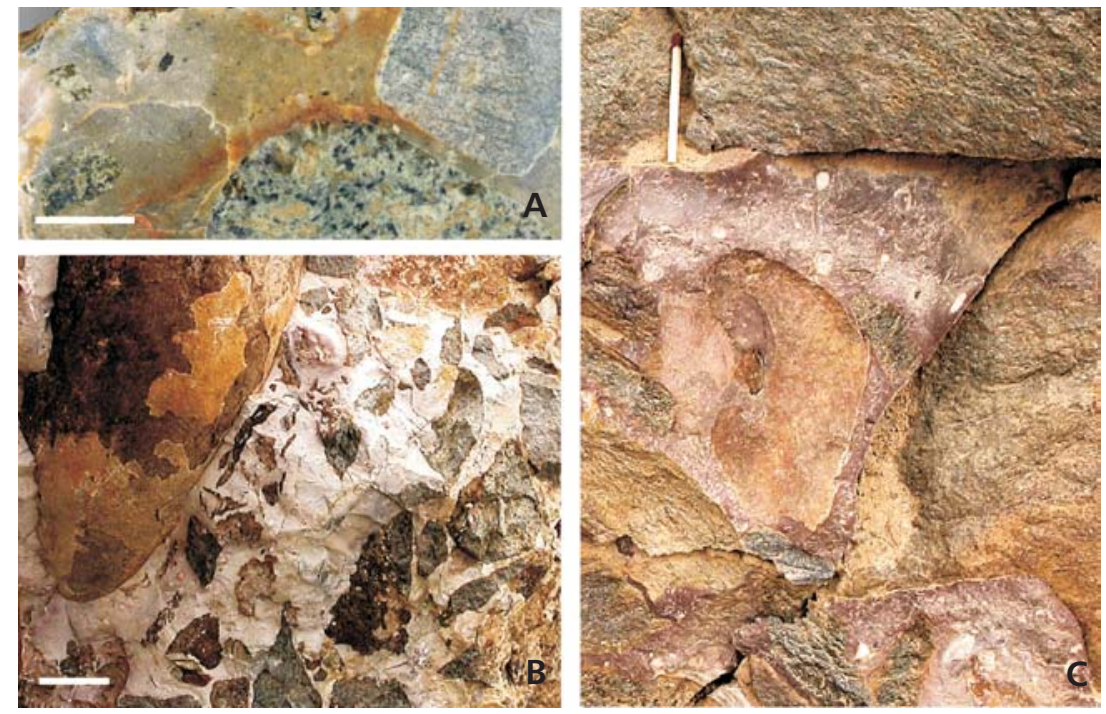

Figure 5. Conglomerate samples. - A - polished section of unit 1 showing diabase and rare granitoid (upper right) clasts in sandy-carbonate matrix. $\bullet$ B - field photo of topmost part of unit 3 , with angular diabase clasts in light limestone matrix. $\bullet \mathrm{C}$ - field photo of unit 3 , about $1.5 \mathrm{~m}$ below the upper erosion surface $\left(\mathrm{e}_{2}\right)$, note the fine-grained reddish limestone matrix with cross sections of fauna. Scale bars: A, B $-10 \mathrm{~mm}, \mathrm{C}$ - match stick is about $4 \mathrm{~cm}$ long.
Macrofaunal features. - Macrofaunal remains are concentrated close to the base and in the topmost parts of the conglomerate as well. Mostly indeterminate, small, and unabraded fragments derived from bivalves, bryozoans, worms, and echinoids [spines of Tylocidaris vesiculosa (Goldfuss), Tylocidaris sorigneti (Desor), elements of echinoid lanterns] were observed in polished sections of hard basal limestone (Fig. 4E). The skeletal remains are highly recrystallized. In the middle parts of the conglomerate, large oysters [Rastellum diluvianum and possibly Rastellum carinatum (Lamarck)], fragments of isolated valves of Neithea sp., and complete tests of the brachiopods Cyclothyris zahalkai Nekvasilová and "Terebratula" biplicata Sowerby are commonest. Identical species occur as high as the upper erosion surface.

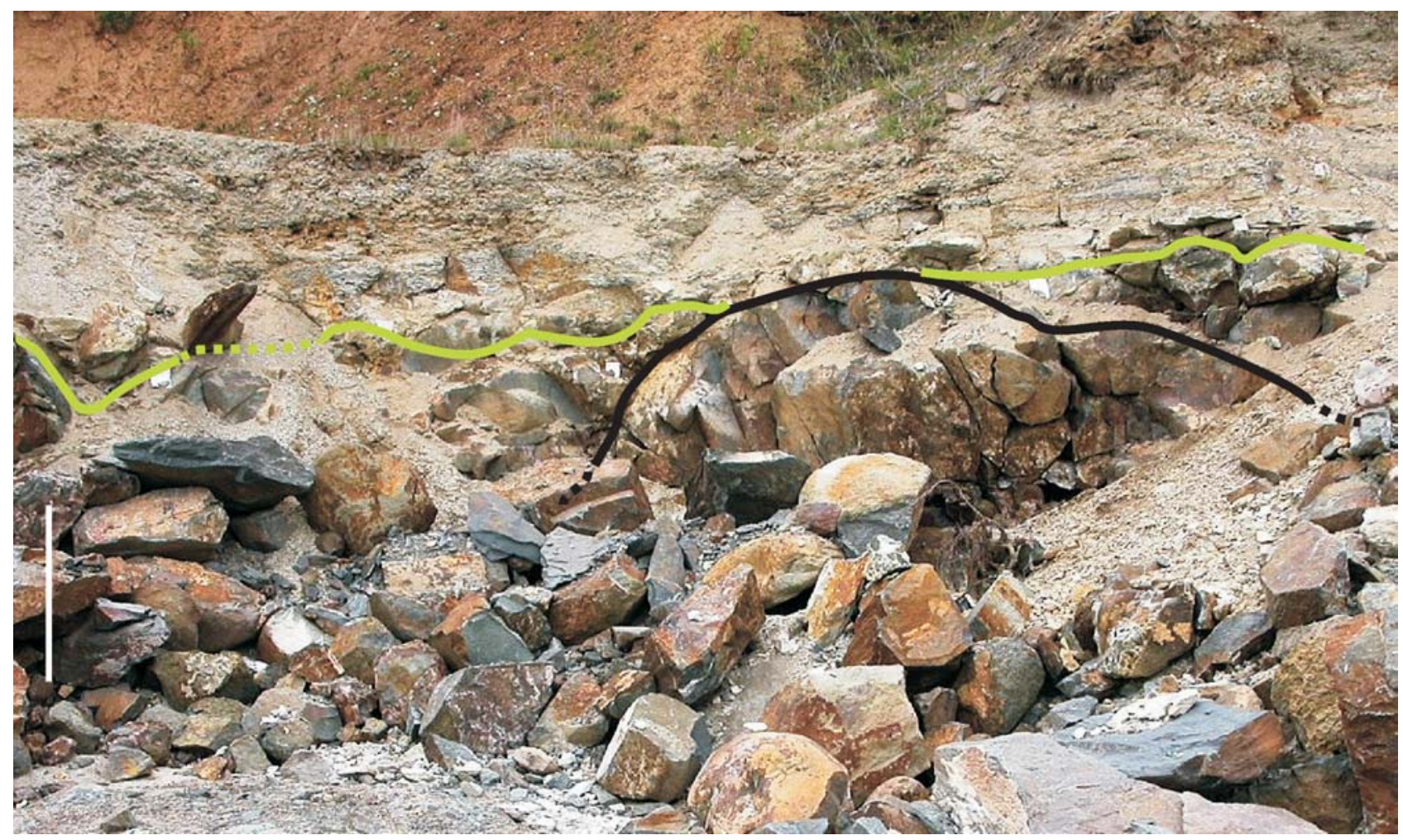

Figure 6. Chrtníky, upper part of the Giant Channel fill near the southern channel wall. Situation in 2005. Solid black line - diabase bedrock surface, green line - level with stromatolites. White scale bar represents $1 \mathrm{~m}$. 
Phosphatic particles, which are probably coprolites, are very rare and measure up to $1.5 \mathrm{~cm}$. About ten specimens of the oyster Amphidonte (Amphidonte) haliotoideum (Sowerby) were found to encrust one diabase boulder, being covered by a $0.5-1.0 \mathrm{~cm}$ thick coating of Fe-rich sediment.

\section{Unit 4. Upper condensation interval}

Position. - This level is composed of: 1. products of processes locally affecting the erosion surface $\left(e_{2}\right)$ on the very top of the upper conglomerate (unit 3 , Fig. 3A), and changing it into the hardground-like surface (hardground sensu lato); and 2. overlying stromatolitic buildups, which may be up to $10 \mathrm{~cm}$ thick (Figs 3C, D, 6, 7).

Lithologic character. - The erosion surface is mostly sharp, frequently with protruding bioclasts. The colour is greenish to brownish (Fig. 7A), depending on the type of mineralization or mineral coatings (nontronite, phosphate). This surface is overlain by the bioturbated unit 5 (Figs 7A, B; see below). However, in many places of conglomerate interstices, the erosion surface is only slightly expressed and is overlain by stromatolitic buildups which may be up to $10 \mathrm{~cm}$ thick (Figs 3C, 7C, D). The latter are composed of mostly thin limestone layers alternating with thin clay coatings or laminae. The limestone is very hard and light (mostly whitish or yellowish), while the clay laminae are green due to clayey particles with green nontronite (for its origin see below in palaeoenvironmental step 2). The vertical succession of laminae shows an irregular pattern. The basal laminae were originally planar (cf. Monty \& Mas 1981, p. 96, fig. 7), the median ones are irregularly composed of mixed planar and colloformic layers (Delamette 1990), while in the top part the planar and wavy laminae prevail again and are the densest. Influxes of limestone with small bioclasts are
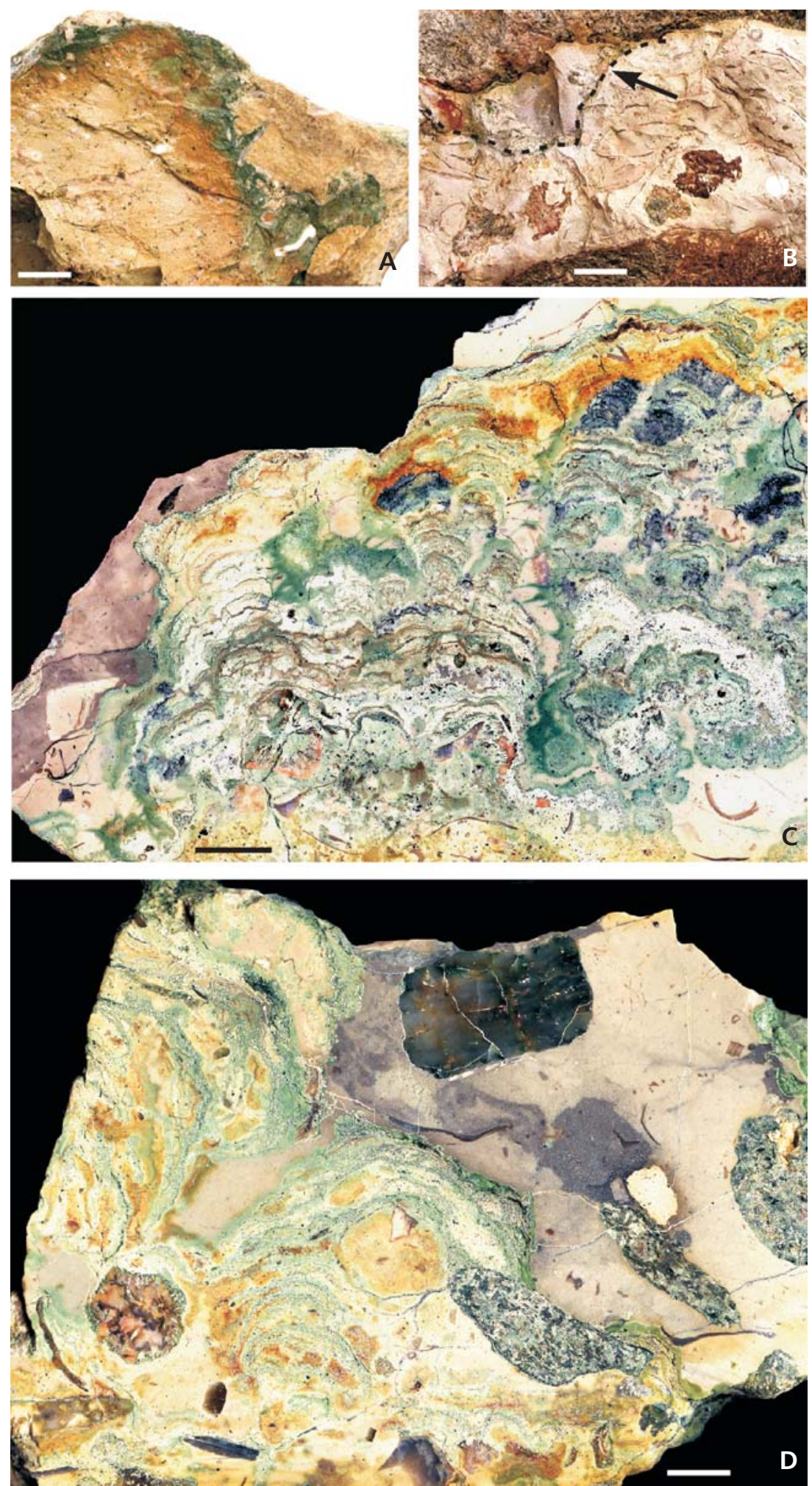

Figure 7. Chrtníky, upper interval of condensed sedimentation. - A - erosion surface $\left(\mathrm{e}_{2}\right)$ [hardground (s. lat.)] with slight phosphatization and green nontronite. Note the sharp-edged bioclasts protruding from the surface. The yellowish overlying rock is bioturbated sediment of unit 5 , altered due to weathering. $\bullet B-$ the same erosion surface between diabase boulders. $\bullet$ C, D stromatolites in polished sections, overlain by bioturbated sediments (units 5, 6). Scale bars: A, B $10 \mathrm{~mm}, \mathrm{C}, \mathrm{D}-5 \mathrm{~mm}$. 

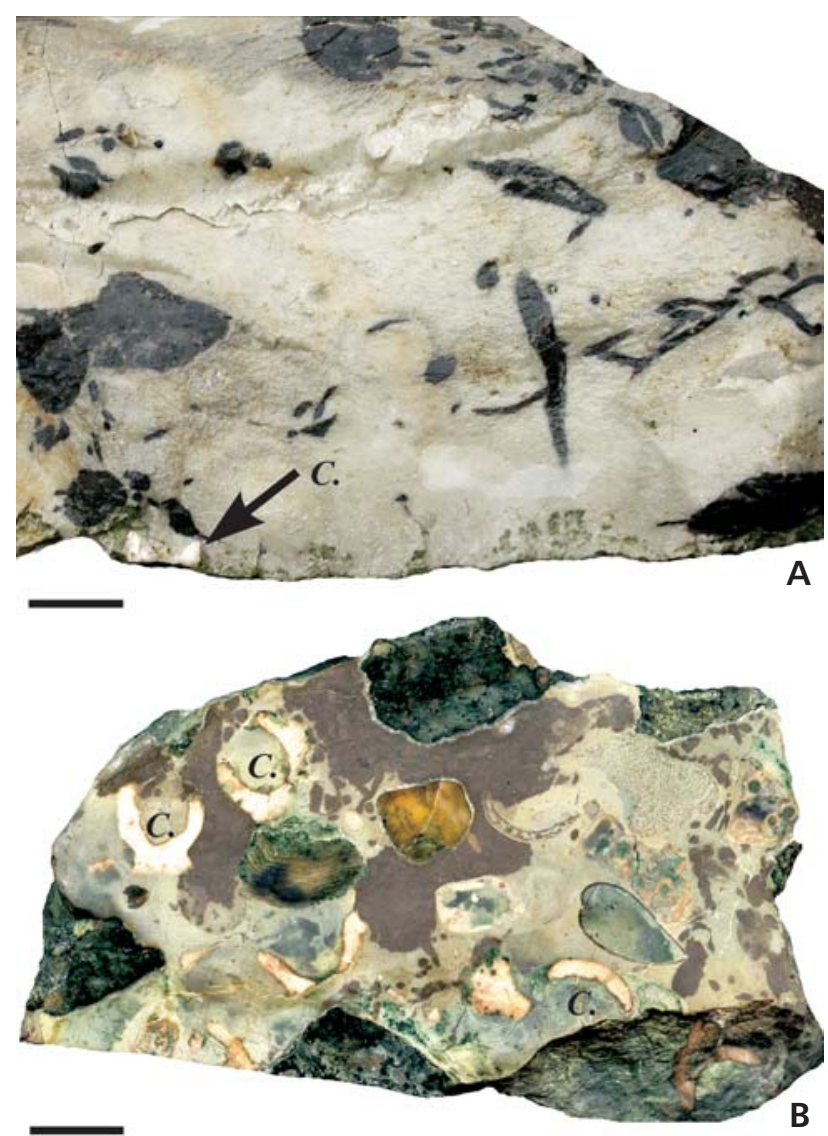

Figure 8. Chrtníky, limestone of unit 5 with bioturbations filled by unit 6. Remains of Cyathidium aff. depressum - arrow and $C$. $\bullet \mathrm{A}$ - broken surface. $\bullet B$ - polished section. Scale bars represent $10 \mathrm{~mm}$.

frequent mostly in the basal portions of the stromatolites. Small diabase and quartz clasts (up to $2 \mathrm{~cm}$ ) are rarely incorporated between laminae (Fig. 7D). The basal stromatolite parts are locally of a blue-green colour and are enriched by pyrite. However, this colour variety seems to form a single genetic entity with the overlying light green to yellowish stromatolite part without any separation by an apparent discontinuity. There are various irregularities in the stromatolite development, e.g., deep limestone penetration into the spaces between stromatolite columns (Fig. 7D), and indications of the disintegration of laminae. The stro- matolite formation was terminated by intensive phosphogenesis, during which the surface laminae were phosphatized and local, thin coatings of massive or very thinly laminated phosphate formed on them. The laterally situated erosion surfaces (hardground $s$. lat.) were also slightly phosphatized, and the phosphatic coatings on adjacent conglomerate boulders (even on corroded ones) formed.

Macrofaunal features. - Basal stromatolite parts underlying the first greenish lamina, formed of light massive limestone, contain abundant small, barely identifiable bioclasts (fragments of echinoid spines, worm tubes, bivalves) and some larger fragments of Ostrea cf. operculata. Fragments of erect bryozoans and diminutive brachiopods are very rare. Thecae of Cyathidium aff. depressum Sieverts and bivalve fragments are rarely found in the limestone of the stromatolite laminae.

\section{Units 5 and 6 . Soft light limestones with dark bioturbations}

Position. - This unit overlies both the stromatolitic buildups and the hardground (s. lat.) surfaces, and is of highly variable thickness (from several up to about 20 centimetres). Its upper surface is erosional (Figs 3B, C).

Lithologic character. - Both the thickness and the lithologic character of the sediment of unit 5 are highly variable. The commonest development is the hard, fine limestone of light, whitish, yellowish, or slightly greyish colour, with only very rare bioclasts or rock and mineral clasts (diabase, quartz) (e.g., Figs 7D, 8A). However, a relatively dark (greenish) coloured deposit also occurs, which locally contains a number of small diabase clasts (up to 6 centimetres in size) and frequent bioclasts (Fig. 8B). Unfortunately, the exact relationship between these two facies in the section is not known, as they are not visible in the same exposure. All features, however, indicate that they are indeed lateral facies. The diabase cobbles are mostly abraded, though ones with uneven surfaces also occur. Small cobbles around $5 \mathrm{~mm}$ may even be angular, some of them altered into green pieces (under study). The limestone is mostly bioturbated.

Figure 9. Chrtníky, macrofauna of unit 7. $\bullet \mathrm{A}$ - rock sample with abundant fossil remains (upper right part - theca of Cyathidium aff. depressum, lower part - spine of Tylocidaris vesiculosa, a.o.). $\bullet \mathrm{B}$ - fragment of corona of Tylocidaris vesiculosa. $\bullet \mathrm{C}-\mathrm{G}-$ five thecae of $C$. aff. depressum; $\mathrm{C}-\mathrm{dorsal}$ view, $\mathrm{D}$ - lateral view, E - lateral view with cemented serpulid tube, F-dorsal view of fragmented but well-preserved specimen, $\mathrm{G}-$ dorsal view of complete but highly abraded specimen. $\bullet \mathrm{H}$ - "Isocrinus" cf. lanceolatus, a pluricolumnal overgrown by a pycnodonteine oyster. $\bullet$ I-K - coral Synhelia gibbosa in three different modes of preservation; I - abraded specimen, $\mathrm{J}$ - fragmented but unabraded specimen, $\mathrm{K}$ - highly abraded, mineralized, and encrusted specimen; one of the phosphatic intraclasts derived from rocks of the oldest Late Cenomanian sedimentary cycle. $\bullet \mathrm{L}-$ dactylopodite of Necrocarcinus sp. - M - spine of Tylocidaris sorigneti with attached foraminifera Acruliammina longa. $\bullet \mathrm{N}$ - fragmentary spine of Tylocidaris vesiculosa with abraded base. - O-P - calcareous sponge Pachytilodia bohemica, lateral and basal views. $\bullet$ Q - ditto with basis oriented downwards. $\bullet$ R - bryozoan Polyceratophora euglypha encrusting theca of $C$. aff. depressum. $\bullet \mathrm{S}$ - bryozoan Reptomultelea tuberculata, a detail of multilamellar colony. Scale bars: A, O-Q - 3 mm, B-N $-2 \mathrm{~mm}, \mathrm{R}, \mathrm{S}-100 \mu \mathrm{m}$. 


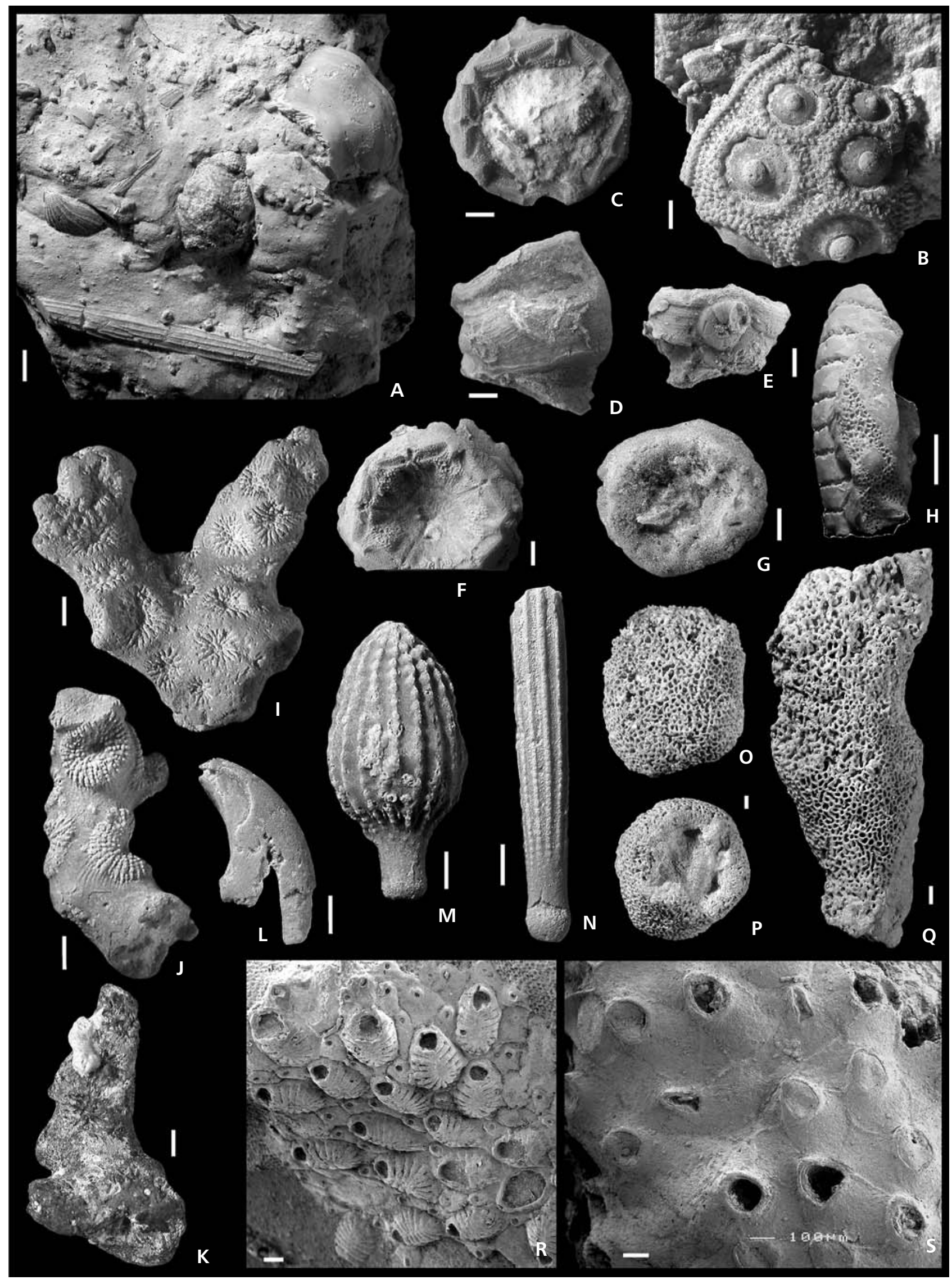


Burrows of several types are filled in with dark grey to black siltstone (unit 6; Figs 3B, C, 7B-D, 8A, B). An identical rock occurs in small relics preserved above the limestone (Fig. 3C). The intensity of bioturbation varies, and locally the dark sediment of unit 6 prevails. The burrowing was clearly a rapid polyphase process, and younger burrows are often concentrated within the older ones. The local mixing with light substrate (the present limestone) is often strong. The lithification of burrow fills depends on their quantitative ratio to the substrate. This means that when the limestone substrate prevails, the burrow fills are cemented into the dark grey limestone. In contrast, the fills remain softer when they prevail.

Macrofaunal features. - The macrofauna of unit 5 is rather poor, but local accumulations of the brachiopod Cyclothyris zahalkai occur. Bivalves (mostly unidentified oyster valves) and thecae of Cyathidium aff. depressum may also be present. Large pieces of the sponge Pachytilodia bohemica Počta, frequently abraded and mineralized, were found in contact or closely above the hardground (s. lat.) and stromatolite surfaces. The fauna of the lithological subtype with diabase clasts (see above and Fig. 8B) is distinctly more abundant and diverse. There also occur bryozoans (both erect and encrusting forms) and worm tubes, but mainly immense numbers of thecae of $C$. aff. depressum (see Fig. 8B). Unfortunately, the rock is so hard that all organic remains are seen in sections only, which makes their identification very difficult. No skeletal remains of macrofauna can be exactly attributed to the dark siltstone of unit 6 forming the burrows in unit 5 .

\section{Unit 7. Bioclastic limestone to marlstone}

Position. - This deposit is bounded by two erosion surfaces ( $e_{3}$ and a locally apparent upper surface; see Fig. 3B), and is about $35 \mathrm{~cm}$ thick. The indistinct upper erosion surface was observed in the GC, but not in the westernmost part of the quarry.

Lithologic character. - This sediment is mostly of yellowish to whitish colour, and occurs in two slightly different lithological types. The basal part (see Fig. 10) is about

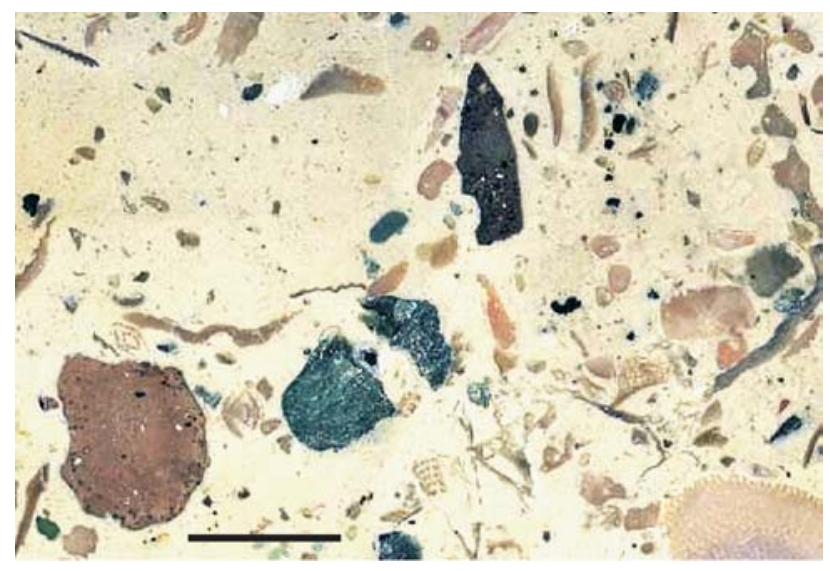

Figure 10. Chrtníky, clayey limestone of unit 7 in polished section; note the small diabase clasts and a phosphatic intraclast (left). Scale bar represents $5 \mathrm{~mm}$.

$25 \mathrm{~cm}$ thick and is formed of relatively hard clayey limestone. Small diabase and quartz cobbles (frequently encrusted by epifauna), which are often only suboval or subangular, were also frequent. Irregular thin streaks of biodetrite alternating with fine, fossil-poor limestone are characteristic. This limestone, which is very massive in its top parts, passes rapidly upwards into about $10 \mathrm{~cm}$ of more clayey limestone with yet more abundant bioclasts. Bioclast abrasion was variable but generally very weak. Phosphatic intraclasts are represented not only by casts of faunal remains, but phosphatized sediment is also abundant in the whole thickness of sediment, though mostly concentrated in the upper parts. The sediment has now been completely removed by quarrying, and does not occur in the section at present. Probable equivalents of basal limestone without Cyathidium remains occur in the middle part of the quarry.

Macrofaunal features. - Macrofauna (Table 1 and Figs 9, 11-13) was very abundant in both lithological types. In addition to the fauna already listed, two further faunal features deserve to be emphasized.

1. An abundance of phosphatic casts of macrofauna, mostly undeterminable due to dissolution of skeletal carbonate. Small oysters resembling young Rhynchostreon suborbiculatum (Lamarck), fragments or complete specimens of the coral Synhelia gibbosa (Goldfuss) and fragments of sponges are most frequent. Ammonite fragments identified by M. Košták (PřF UK Prague) as Sciponoceras gracile

Figure 11. Chrtníky, fauna of unit 7. • A, B, D - Ostrea cf. operculata; A, D - inner shell surfaces, B - outside view of shell in Fig. 11 A with small epibionts (arrows with J, K - see Figs 11J, K). $\bullet \mathrm{C}$ - small Pycnodonte (Phygraea) vesiculare encrusting a phosphatic intraclast. $\bullet$ E-I - two opercula of Neritopsis sp.; E, F - unabraded specimen; G, H - abraded and bioeroded specimen; I - close-up view of Fig. 11H, note the attached foraminifera Acruliammina longa. $\bullet \mathrm{J}, \mathrm{K}-$ small epibionts attached to the outside surface of shell in Fig. 11B. $\bullet$ L-M - free valve of small oyster Amphidonte (Amphidonte) reticulatum in inner $(\mathrm{L})$ and outer $(\mathrm{M})$ views; arrow on Fig. $11 \mathrm{~L}$ - attached A. longa (close-up view in Fig. 11O), arrow in Fig. $11 \mathrm{M}-$ attached valve of juvenile oyster A. (A.) reticulatum (close-up view in Fig. $11 \mathrm{~N}$ ). $\bullet \mathrm{P}$ - juvenile oyster Pycnodonte (Phygraea) vesiculare encrusting a bivalve fragment. $\bullet \mathrm{Q}-$ abraded fragment of valve of Inoceramus ex gr. labiatus with attached small A. longa. Scale bars: A-D, L, M - 3 mm, E-H, P, $\mathrm{Q}-2 \mathrm{~mm}, \mathrm{~N}, \mathrm{O}-1 \mathrm{~mm}$. 


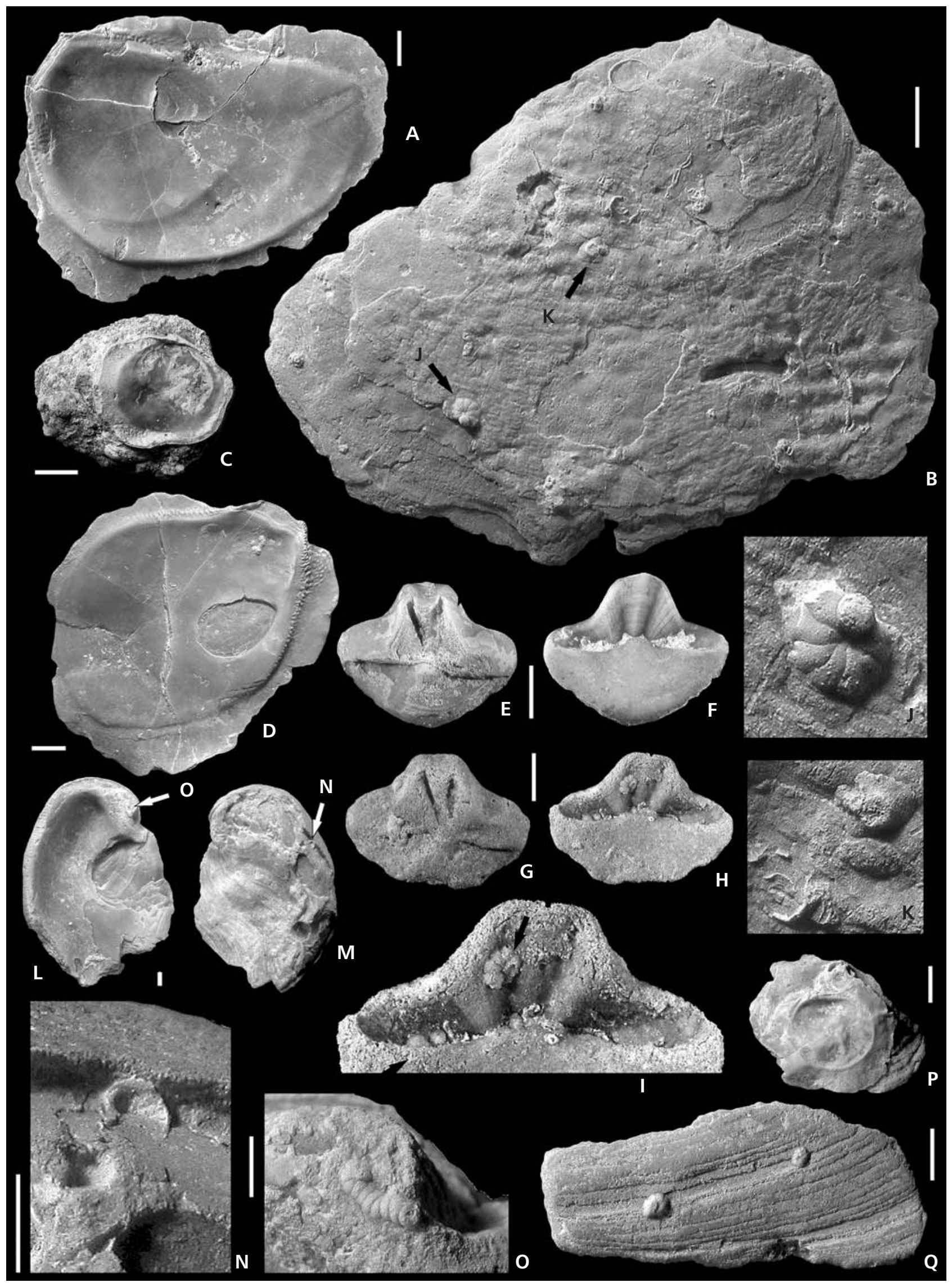


(Shumard) are rare but stratigraphically important (see Discussion and conclusions). All intraclasts are frequently encrusted by small epifauna.

2. An accumulation of thecae and brachial elements of Cyathidium aff. depressum, concentrated mainly in the top clayey limestone horizon (in preparation for publication). The exceptional find of Inoceramus ex gr. labiatus (Schlotheim) indicates an Early Turonian date for this horizon.

\section{Unit 8, beds a-e. Siltstones with sponges}

Position. - These sediments overlie unit 5 (with unit 6 in bioturbations) and 7 in a preserved thickness of 1.5-2 metres (Figs 3, 6). Basal deposits (bed a) often penetrate deeply into the conglomerate, but even the overlying beds $b$ and $\mathrm{c}$ are found locally within the wider topmost conglomerate interstices.

Lithologic character. - The siltstones are mostly greyish with frequent yellowish streaks or islets. They are distinctly stratified, and massive hard intercalations are frequent (beds a, c, and e). The basal sediment of bed a, rich in large sponges, is very hard, calcareous, and most basally enriched by smaller bioclasts (e.g., Fig. 14N). At least two thin horizons with very small burrows are developed in bed a. Bioclasts are rarer in the softer siltstone beds (beds b and d). Small, only slightly abraded diabase clasts "float" in the siltstones, mainly in bed a, but large diabase boulders with deeply corroded surfaces of light colours occur as high as bed d (Fig. 3B). The unstable character of the harder beds must be accentuated here, because they are developed only near the southern channel wall (near the opposite wall there are only Quaternary redepositions at this level), and all of them pass into the soft siltstones occurring near the channel axis. Irregularities in the boulder positions together with irregularities in interstitial sedimentation do not permit precise correlation of the marginal channel bedding with the relatively uniform sediment mass in the central channel position (from which the majority of fossils was collected). Experience gained at other outcrops in the quarry and even at some other Bohemian localities shows the harder beds and their number to vary locally.

Macrofaunal features. - Sponges are the typical and the most abundant component of taphocoenoses (Table 1 and Figs 14A-F, I-K, 15). They are mostly accumulated in the harder beds a, c, and e. Flat and large lithistids prevail in the basalmost portions of bed a. The sponge skeletons are fragmentary (especially the flat, wide forms) but frequently occur complete. Pressure deformation of the sponges, caused by sediment compaction, is also common (Fig. 15C). The flat lithistid sponges and their fragments are deposited mostly parallel to bedding, especially in bed a. The sponges bear several taxa of cementing epibionts with bryozoans, foraminifera, and bivalves Atreta sp. prevailing; for more details see below. Taphocoenoses of sponge beds b-e indicate a general impoverishment of individuals of other faunal groups.

\section{Unit 8, bed f. Clayey siltstone with diverse macrofauna}

Position. - This sediment overlies the sponge bed e and is about 1-1.4 metres thick (Fig. 3A). Its top parts were affected by Quaternary processes, so the original thickness of this deposit is unknown.

Lithologic character. - In basal parts the sediment is well preserved, not influenced by weathering or Quaternary destructive processes. This is clayey and passes rapidly into local more silty parts, but as a whole it is soft and of greyish to slightly yellowish colour. Bioclasts are extraordinarily abundant and mostly concentrated near the southern channel wall. They demonstrate a very wide scale of preservational types. Strongly corroded and bioeroded bioclasts are frequent. Other clasts (diabase, quartz) are nearly absent and, when present, are of small cobble size.

Macrofaunal features. - The enormously abundant macrofauna is listed in Table 1 and figured in Figs 14G, H, L, M, 16 and 17 . Rich bryozoans, scarce sponges, and relatively abundant isocrinid columnals, pluricolumnals, and cidarid plates and spines are the most typical elements. The bioclasts are abundantly encrusted by small epibionts (foraminifers, worms, Atreta sp., bryozoans).

\section{Comparison of Giant Channel with other outcrops at the quarry}

The recently uncovered Cretaceous deposits crop out mostly along the northern quarry wall (Fig. 1B), and are almost

Figure 12. Chrtníky, macrofauna of unit 7. • A-C, E - "Terebratula"? biplicata; A, B, E in dorsal views; C-specimen in Fig. 12B in ventral view with arrow showing etching trace Podichnus sp. (close-up view in Fig. 12D). • F, G - Terebratulina "chrysalis" in dorsal views; F - a young specimen. H Cyclothyris zahalkai in ventral view with attached serpulids (in detail see Fig. 12I). $\bullet \mathrm{J}, \mathrm{K}-$ two shells of the same species in dorsal views. $\bullet$ L Cycloserpula gordialis. $\bullet \mathrm{M}-$ Serpula cf. rauca. $\bullet \mathrm{N}, \mathrm{O}-$ Amphidonte (A.) reticulatum in outer and inner views. $\bullet \mathrm{P}, \mathrm{Q}-\mathrm{attached}(\mathrm{eft}) \mathrm{valve}$ of Gryphaeostrea canaliculata in lateral view with base downwards $(\mathrm{P})$ and oblique view of attaching surface $($ base $) \cdot \bullet \mathrm{R}, \mathrm{S}-$ ditto in outer and basal views. Scale bars: A-C, E-H, J, K, N, O - 5 mm, D - $1 \mathrm{~mm}, \mathrm{~L}, \mathrm{M}, \mathrm{P}-\mathrm{S}-2 \mathrm{~mm}$. 


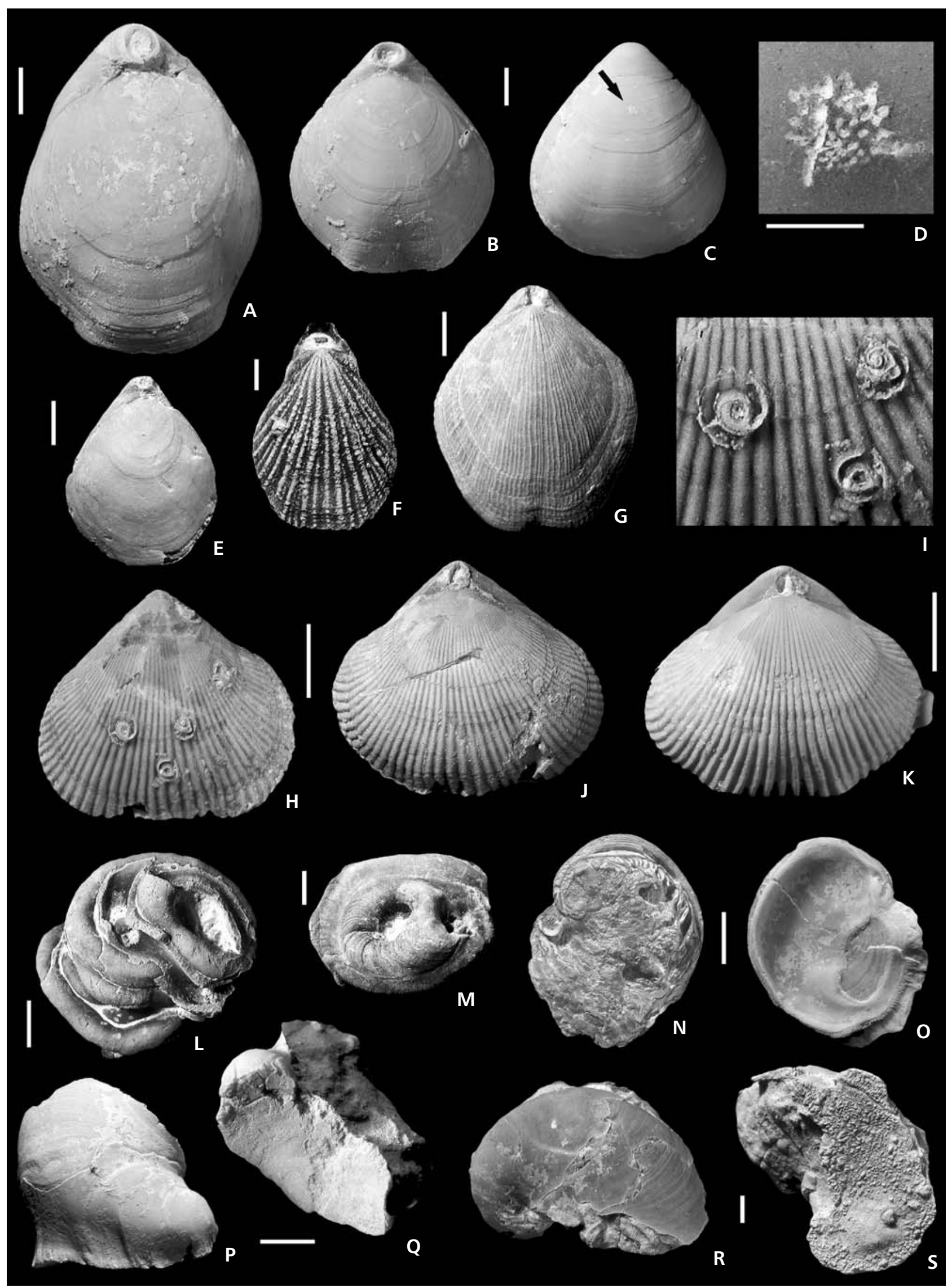


inaccessible. The largest depression is also a cross-cut channel about 10 metres deep, directed approximately downslope (close to the corroded rock - see Fig. 1B). The channel fill is in basal and topmost parts identical to the Giant Channel (GC) (the units 1, 3, 7, 8 - bed a), but the middle parts could not be studied. The most important is the westernmost depression fill (Fig. 1B), which is about 6 metres thick (the base is not visible) where all preserved facies [units 1-8 (bed a, and possibly bed b)] correlate well with those of the GC. The massive carbonate matrix of the topmost conglomerate horizon of unit 1 is locally very dark red, or dark brown to brown-black, and is very rich in inertinite. Deposits of the lower condensation interval are about $3-4 \mathrm{~cm}$ thick, but only limited material was collected from it due to covering by rock debris. The lowermost part of the conglomerate matrix of unit 3 is formed of identically coloured, hard and dark limestone, which passes upwards into the reddish, and in the top parts light greyish, limestone. All these carbonates are rich in fossils including the oyster Rastellum carinatum, which is missing in the coeval limestone of the GC. All of the fauna is fragmented and disarticulated (except the brachiopod C. zahalkai), and frequently abraded. Valves of large oysters are mostly complete. The contact between these limestones and the overlying stromatolite (upper condensation interval) is most probably erosional. Deposits of unit 7 are a little impoverished in fauna and do not contain Cyathidium remains. They may possibly be correlated with basal part of unit 7 of the GC. Above the central part of the northern quarry wall is a small rock (diabase) elevation, about 3 metres high (for its location see Fig. 1B), with a corroded surface occupied by many cementing epibionts (Atreta sp. 2 prevailing). When projected by a horizontal shift to the GC, the top of the rock is about 4 metres above the base of unit 8 , bed $\mathrm{f}$.

\section{Sponge and bryozoan assemblages}

Sponges and bryozoans are highly significant components of the Chrtníky taphocoenoses. They are well preserved and abundant, mostly in the uppermost strata.

The sponge assemblages at Chrtníky are highly diverse at the species and genus levels, and range from units 5 to 8 (bed f) (see Table 1 and Figs 14, 15). The sponges reflect the deepening of the sea floor across preserved parts of two Early Turonian sedimentation episodes. Conclusions about the relative bathymetry are based on recent equivalents of calcareous-lithistid-hexactinellid sponge distribution (e.g., Krautter 1997). Sponges have not yet been used as a bathymetric indicator in the Bohemian Cretaceous Basin.

The studies at Chrtníky allow the distinction of three local sponge assemblages. Although their occurrence is also indicated at several other localities (e.g., Velim, Nová Ves, Plaňany) of nearshore facies, the wider extent of these assemblages in the BCB must be carefully verified. The most relevant is the need for taxonomic revisions of many sponge taxa in the BCB, the status of which is sometimes unclear and descriptions are poor.

The first recognized assemblage, i.e., the "Pachytilodia bohemica assemblage" indicates the shallowest and most agitated environment of the Early Turonian sedimentation in the Chrtníky area. The second, "Chonella-Verruculina-Siphonia assemblage" represents a transition between the shallow-water "Pachytilodia bohemica assemblage" and the third, relatively deep-water "Laocoetis-Guettardiscyphia-Diplodictyon assemblage". The quantitative ratios of hexactinellids, demosponges, and calcareous sponges used in characterizing the assemblage reflect only the relative depth of the sea. No data on absolute depths are presently available.

Skeletons of the calcareous sponge Pachytilodia bohemica Počta prevail among the sponges of the "Pachytilodia bohemica assemblage". This assemblage ranges from units 5 to 7 (Figs 9O-Q, 13D). Robust fragments or complete specimens of this sponge are up to 17 centimetres in size. They frequently bear traces of fragmentation, abrasion, and the post mortem exposure of their skeletons in a high-energy environment, especially in unit 5. When occurring in contact with hardground (s. lat.) or stromatolites, they are of greenish or brownish colours and contain nontronite and phosphate. Indeterminate fragments of lithistids compose a small minority in this assemblage.

The great majority of sponges from the "Chonella-Verruculina-Siphonia assemblage" belong to the class Demospongiae (see Table 1 and Figs 14, 15). This assemblage occurs in beds a-e of unit 8 . Sponges occur in lenses inside the calcareous siltstones. They sometimes form densely packed accumulations of well-preserved skeletons, indicating deposition closely adjacent to their original positions. The plate- to funnel-shaped lithistid sponges Chonella (Fig. 15C), Seliscothon, and Verruculina (Figs 14A, F) are accumulated in basal sediments of

Figure 13. Chrtníky, macrofauna of unit 7 and epibionts of diabase clast. $\bullet$ A, B - colony of bryozoan Reptomultelea betusora in upper and lateral views. $\bullet$ C, E - bryozoan Reptomultelea sarthacensis (E - a colony overgrowing small bivalve shell). $\bullet$ D - sponge Pachytilodia bohemica (specimen figured in Fig. 9Q) with attached colony of $R$. betusora (arrows). $\bullet \mathrm{F}$ - basal attaching surface of coral Moltkia foveolata with imprinted structure of its original substrate, i.e. of an exhalant surface of sponge Verruculina sp. $\bullet \mathrm{G}, \mathrm{H}$ - basal part of Moltkia foveolata in basal and upper views; see bioerosion traces. - I - ditto with attached juveniles of Amphidonte (A.) reticulatum. $\bullet \mathrm{J}, \mathrm{K}$ - parts of Moltkia foveolata; $\mathrm{J}$ - fragment of upper part viewed laterally, $\mathrm{K}$ - basal attachment part in the same view. $\bullet \mathrm{L}$ - coral Anthophyllum cylindricum in lateral view. $\bullet \mathrm{M}$ - base of coral Trochosmilia sp. and foraminifer Bdelloidina cribrosa (lower part of the photo) attached to a diabase boulder. Scale bars represent $2 \mathrm{~mm}$. 


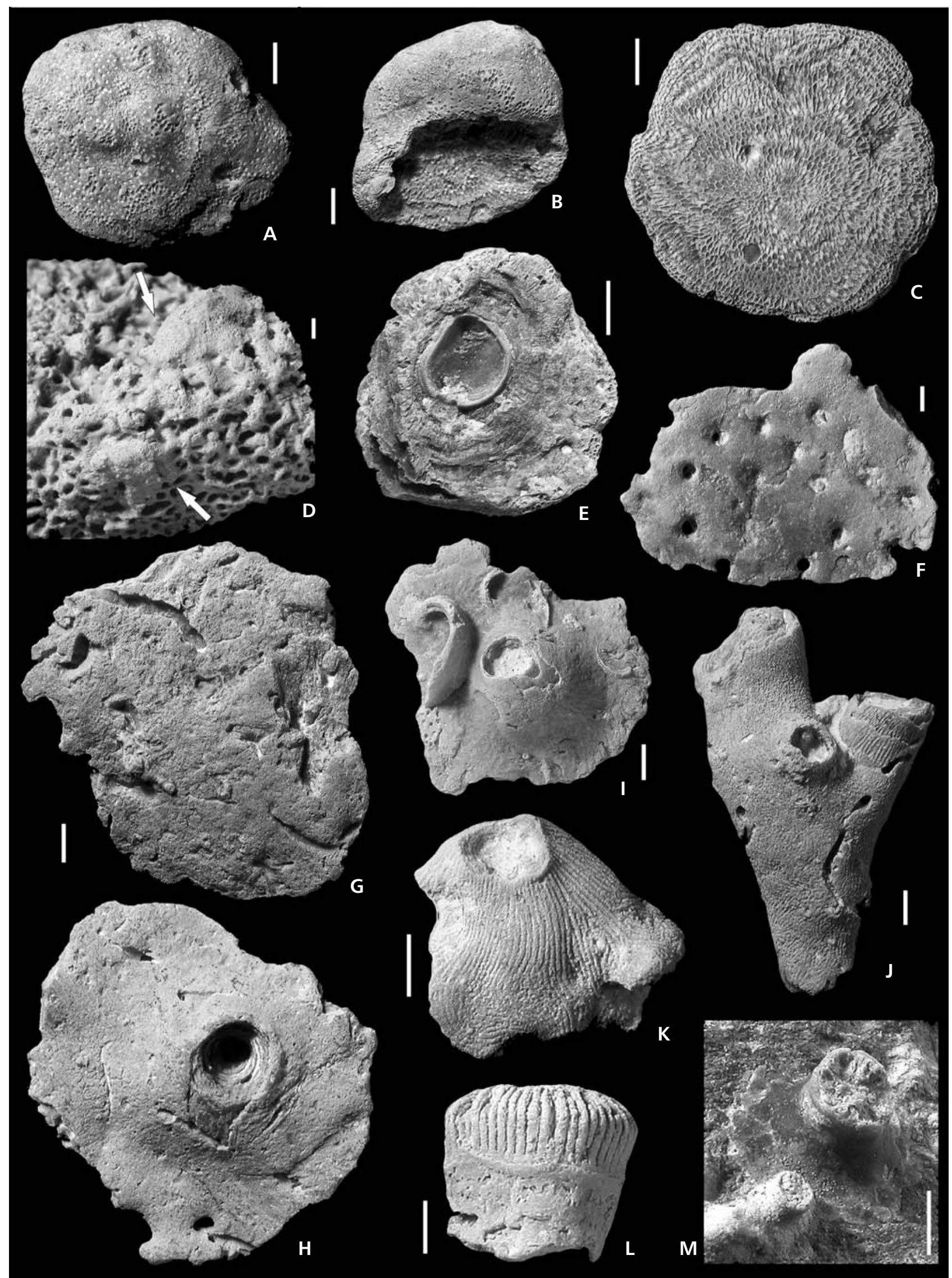


the sponge beds (unit 8, bed a). The genus Siphonia (Figs 15K, L) is also very common in this assemblage. The percentage of hexactinellid sponges increases from the upper part of bed a to bed e, although demosponges are a major component of the assemblage.

The sponge skeletons are relatively less abundant in bed $\mathrm{f}$ of unit 8, where they are estimated to represent less than 5 percent of all macrofaunal remains. As demosponges are found only rarely, hexactinellids form the main component of the assemblage. This "LaocoetisGuettardiscyphia-Diplodictyon assemblage" (Figs 14G, $\mathrm{H}, \mathrm{K}-\mathrm{M}$ ) points to formation in the deepest environment of all three sponge assemblages found at Chrtníky.

Bryozoan associations examined here come mainly from unit 7 and unit 8 , bed f. In unit 7 there occur mostly multilamellar colonies of the melicerititid cyclostome bryozoans Reptomultelea tuberculata (d'Orbigny) (Fig. 9S). Crinoid thecae (Cyathidium aff. depressum) are often encrusted by small stomatoporid colonies of Voigtopora and by the cribrimorph Polyceratophora (Fig. 9R). Bed f of unit 8 is dominated by erect, robust colonies of Tholopora (Fig. 17H), but many erect, robust branched colonies of Osculipora (Fig. 17E) and multilamellar colonies of Reptomultelea sarthacensis (d'Orbigny) (Fig. 17F) also occur. For some other species see Figs 17A-D, G, and Table 1.

According to McKinney \& Jackson (1989) and Zágoršek (1996), the association of Bryozoa with dominant encrusting forms represents a shallow and warm-water environment. Consequently, the number of erect growth forms increases with depth and introduction of cooler water. Regarding this generalization, the bryozoan assemblage from unit 7 probably represents a shallower and warmer palaeoenvironment than that of unit 8 , bed $\mathrm{f}$, while the bryozoans of units 8 , beds a-e are transient. This conclusion is consistent with patterns in sponge distribution.

\section{Taphonomy and palaeoecology}

Taphonomic data were only obtained from some units of the GC and other Chrtníky sections. The main difficulty was with the compact limestones and the fragility of the fossils. However, the taphonomic features of the macrofaunal remains, when obtained in sufficient number, seem to agree with the sedimentary environmental conditions indicated by the individual lithologies. Some of the studied features of bioclasts (mainly encrustation) exceed the bounds of taphonomy, as they could be gathered during the host's life. Nevertheless, these palaeoecologic data are of taphonomic importance when used for evaluating the post mortem fates of the host and the epibionts. The same is true for rock substrates and the fossils encusted thereon (see below).

The high-energy conglomerate accumulations (see above, units 1 and 3) contain faunal remains corresponding to high-energy taphonomic features only in their lower parts (high degree of fragmentation, disarticulation, abrasion). However, these features weaken upwards and only full disarticulation is documented. This trend is in accordance with changes in matrix composition, which becomes more carbonate and finer upwards, sometimes of pelagic appearance.

During intervals of condensed sedimentation there was a slight input of bioclasts into the deeper dysoxic (or anoxic) zone of sedimentary stagnation. The sediment of phosphatic islets of the first condensation interval contains abundant small (around 1-3 mm) bioclasts, mostly slightly abraded but sometimes well preserved (indeterminate small disarticulated bivalve). Isolated valves of large indeterminate oysters (probably $O$. operculata and $R$. diluvianum) are visible only as cross sections in the grey massive limestone; they supply no taphonomic data, except that they are always disarticulated. Sponges (Pachytilodia bohemica) undoubtedly belong to the second condensation interval, lying on or closely above the hardground (s. lat.) surface and overlain by unit 5 . They are mostly fragmented and slightly abraded, demonstrating their derivation from a shallower setting. At their final deposition site they were often mineralized similarly with the underlying hardground. Bioclasts directly associated with stromatolite buildups are mostly bivalve and Pachytilodia bohemica fragments.

Taphocoenoses of calcareous oozes deposited in deeper interstices (unit 5) above stromatolites are very poor in species, probably due to weak canalization through the system of narrow spaces between clasts. Rare larger remains (e.g., Cyathidium) document a macrofauna similar to unit 7. Articulated and well-preserved brachiopods of a wide size range (Cyclothyris zahalkai) form only local accumulations, indicating the abrupt input of parts of populations living in the more agitated environment above the conglomerate.

Figure 14. Chrtníky, fauna of unit 8, beds a-e (Figs A-F, I-K, N) and bed $\mathrm{f}(\mathrm{G}, \mathrm{H}, \mathrm{L}, \mathrm{M}) \cdot \bullet \mathrm{A}$ - sponge Verruculina phillipsi, exhalant surface with postica overlain by the attached base of octocoral Molkia foveolata and by other epibionts (e.g., encrusting bryozoan Onychocella reussi - see Fig. 14B, and foraminifer Acruliammina nekvasilovae - see Fig. 14C). D - sponge basis encrusted by Atreta sp. 1. $\bullet$ E - a sponge Laocoetis vulgata encrusted by two generations of oysters Hyotissa semiplana. $\bullet \mathrm{F}-$ Verruculina phillipsi, exhalant surface with small epibionts (see text). $\bullet \mathrm{G}, \mathrm{H}, \mathrm{K}-$ Guettardiscyphia sp. in lateral view $(\mathrm{G})$, close-up view with a dictyonal skeleton $(\mathrm{H})$ and upper view $(\mathrm{K}) . \bullet \mathrm{I}, \mathrm{J}-$ Astrobolia conglobata, general view of exhalant surface (I) and close-up view of postica from which shallow, superficial furrows radiate $(\mathrm{J}) \cdot \bullet \mathrm{L}-$ Laocoetis vulgata in upper view. $\bullet \mathrm{M}$ - fragment of outer surface of lychniscosan sponge Diplodictyon heteromorphum with the oyster Gryphaeostrea canaliculata situated in a depression of uneven wall surface. $\bullet \mathrm{N}-\mathrm{a}$ bivalve Chlamys sp. (found in basal part of bed a). Scale bars: A, D-G, J-L, N-5 mm, B, C, H, M-2 mm, I- $10 \mathrm{~mm}$. 


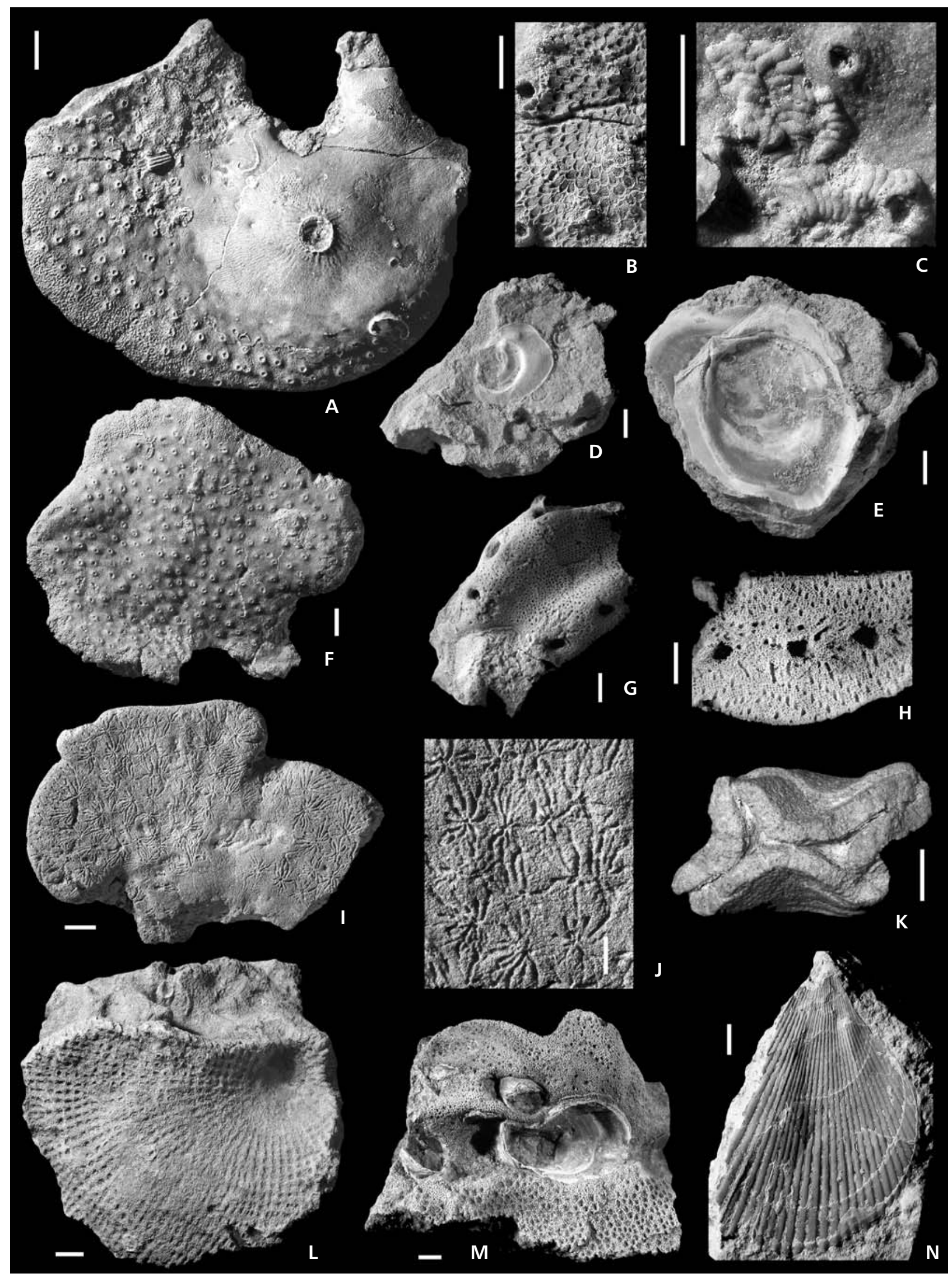


The remains of macrofauna in the deposits of unit 7 are important mostly because of complete disarticulation (except for the majority of brachiopods, see Figs 12A-K). Rare crinoid pluricolumnals may occasionally show encrustation by pycnodonteine oysters, probably when the crinoid was still alive or immediately post mortem. This encrustation prevented columnals from becoming disarticulated (Fig. 9H). Loose opercula of Neritopsis sp. show different styles of preservation and degree of foraminiferal encrustation [Acruliammina longa (Tappan), Bullopora sp., Figs 11E-I], probably due to differing residence time on the sea floor. On the other hand, the majority of isolated bivalve valves are only rarely encrusted on the inner surfaces, but the external valve surfaces are abundantly bioeroded and encrusted (compare Figs 11A, B, D). Young specimens of the foraminifer $B$. cribrosa and a base of a small octocoral specimen were also found (Figs 11J, K). Prevailingly external bioerosion and encrustation indicate not only the prevailing pre-mortem processes, but also rapid burial after death and separation of valves (external epibionts did not suffer any destruction). This is consistent with frequent preservation of the thin marginal valve parts. Identical features show small oysters Gryphaea canaliculata (Sowerby) with very thin walls of attached valves and practically no epibionts (Figs 12P, R). Post-mortem removal of their upper valves indicates a somewhat delayed yet abrupt burial. The smooth or slightly coarser bases of these oysters (Figs 12Q, S) indicate respective types of colonized substrates (abraded rock or clast surfaces, large smooth bioclasts) present on the bottom. Some of the bivalve remains, including those with rather thick valves (e.g., Inoceramus), occur only in fragments, many of which are abraded and encrusted (Fig. 11Q). The majority of encrusters in unit 7 are rapidly growing opportunists such as the foraminifer Acruliammina longa [see Tylocidaris sorigneti spine on Fig. 9M and A. (A.) reticulatum on Fig. 11O], the large foraminifer Bdelloidina cribrosa (Reuss) (see oyster shell on Fig. 11J), the small worm Neomicrorbis (see the test of brachiopod Cyclothyris zahalkai on Fig. 12I, and the Cyathidium theca on Fig. 9E), bryozoans (see the Cyathidium theca on Fig. 9D), small oysters (see larger oyster shell on Fig. 11N). The fragmentation is high in long objects, mainly in spines Tylocidaris vesiculosa. The organic remains in the taphocoenosis indicate relatively low time-averaging with earlier, recycled, strongly corraded (see Brett \& Baird 1986) specimens (excluding intraclasts). Sessile cementing forms mostly colonized the skeletal debris and perhaps also hard substrates that were already colonized with small encrusters, frequently overgrown, and preserved in the attachment bases (e.g., bases of Cyathidium aff. depressum). Large massive eleid bryozoans (Fig. 13C) often colonized smoother (rock, clasts, large oyster?) surfaces, but they were also attached to small bivalves, and could widely overgrow them onto the surrounding substrate (Fig. 13E). These bryozoans could, however, colonize practically all substrate types, including the skeletal mesh of dead sponges devoid of organic matter (see Pachytilodia bohemica on Fig. 13D). The imprints on basal attachment surfaces may sometimes indicate the occurrence of organic substrates still not found in unit 7, as shown by the octocoral base Moltkia foveolata with an imprint of the exhalant surface with postica belonging to the sponge Verruculina sp. (Fig. $13 \mathrm{~F})$. The bioerosion of organic remains is frequent, especially of larger ones (Figs $13 \mathrm{G}, \mathrm{H}, \mathrm{J}$ ). A special type of bioerosion, the etching trace Podichnus sp. produced by brachiopod pedicles, was found on the ventral valve of Terebratula? "biplicata" (Figs 12C, D) (see Nekvasilová 1975, 1986). It may be concluded that there are no signs of the bioclasts having been sorted by size and shape in the taphocoenosis which was probably rapidly derived from locally formed thanatocoenoses. The composition of taphocoenosis corresponds to highly diverse benthic populations. The phosphatic intraclasts and small cobbles derived from older sediments show very short-term residence on the sea floor and their rapid burial, as they are encrusted by rapidly growing opportunists (see above; Figs 11C, 21).

The sponge skeletons of unit 8 , beds a-e, which are preserved as fragments (especially flat, wide forms) and frequently also as complete specimens, show mostly only short transport distances. The flat sponges and their fragments are deposited mostly parallel to bedding, especially in bed a, indicating current-influenced gradual input from close proximity. The abrasion of sponges is very low or absent.

The sponges often functioned post-mortem as islands for cementing epibionts, the diversity of which was, however, very low, with prevailing rapidly growing opportunists (mainly foraminifera and bryozoans; see above) and rarely by octocorals, the oysters Amphidonte (A.)

Figure 15. Chrtníky, fauna of unit 8, beds a-e. - A, B - sponge Scytalia sp. in lateral view and encrusting colonies of the bryozoans Plagioecia cf. papillosa and Reptomultelea betusora on the upper sponge part (for some of them see arrows). $\bullet \mathrm{C}-\mathrm{sponge}$ Chonella sp. in lateral view. $\bullet \mathrm{D}$, E - sponge Astrobolia plauensis, inhalant and exhalant surfaces; E - hexactinellid sponge Laocoetis vulgata encrusting central part of sponge exhalant surface (arrow). $\bullet$ F-I - epibionts encrusting upper surface of the same specimen; F - the oyster Pycnodonte (Phygraea) vesiculare bearing some other epibiont species [Amphidonte (A.) reticulatum], and the worm Mucroserpula sp. (fig. 15H); $\mathrm{G}-\mathrm{a}$ worm tube ?Spiraserpula spirographis attached to upper sponge surface; I - Cycloserpula gordialis on the base of the sponge. $\bullet \mathrm{J}-$ sponge Botroclonium arborescens in oblique view with base downwards. $\bullet \mathrm{K}$, L sponge Siphonia sp. $\bullet$ M, N-sponge Cytoracia obesa in lateral and oblique upper views. Scale bars: A, B, F, G, I-N - 5 mm, C-E-10 mm, H-2 mm. 


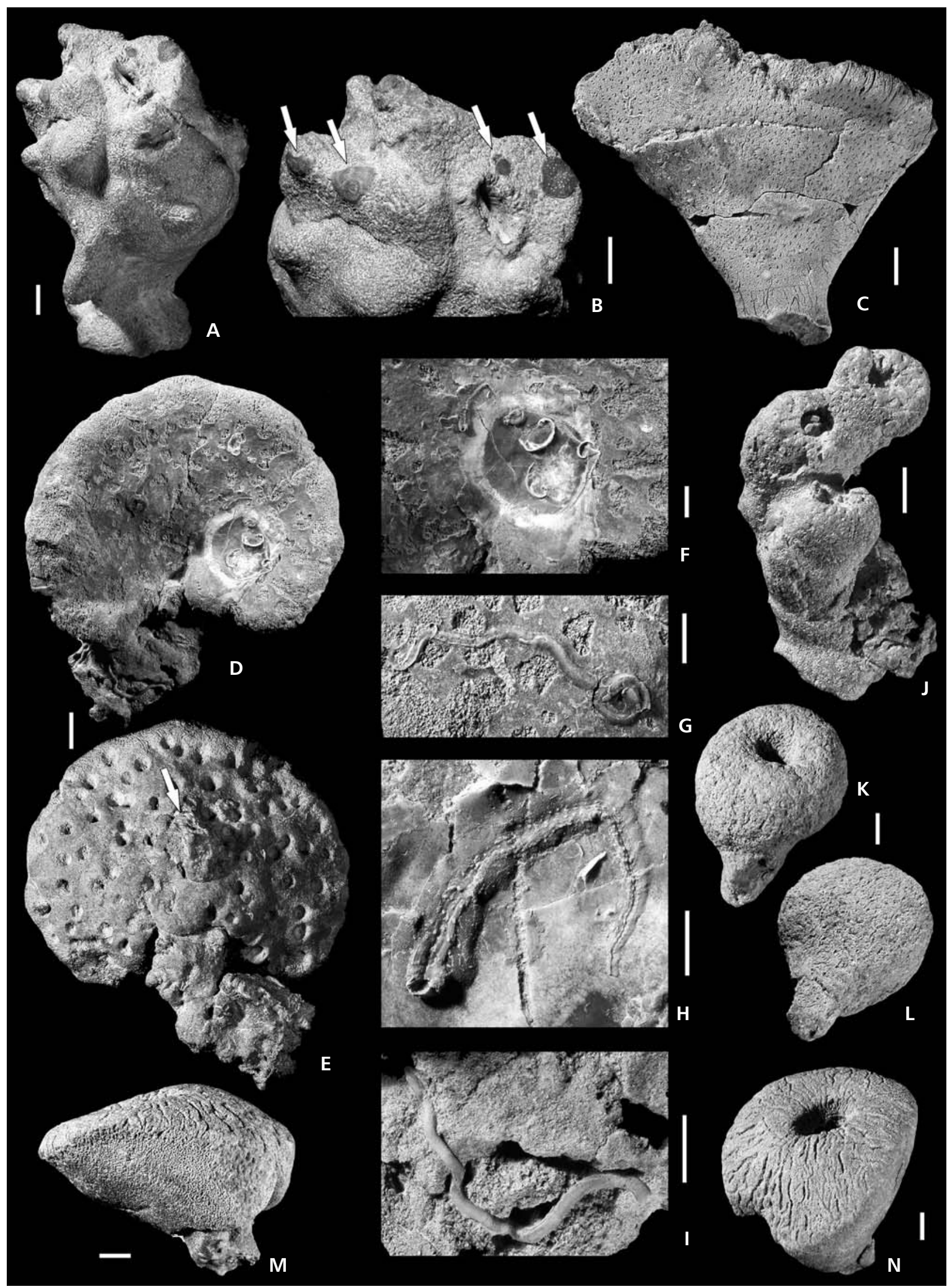


reticulatum, Gryphaeostrea canaliculata, Pycnodonte (Phygraea) vesiculare, and Hyotissa semiplana (Figs 14A, E, M, 15D), the brachiopods Ancistrocrania? gracilis, and Praelacazella lacazelliformis, and the bivalves Atreta sp. 1 and sp. 2 (Fig. 14D). For an instructive example see Fig. $14 \mathrm{~A}$, where the base of the octocoral Moltkia foveolata covers more than one half of the sponge upper surface, with about five other small epibiont species co-occurring on both the coral and the sponge, including the foraminifer Acruliammina nekvasilovae Hercogová (Fig. 14C), which is a very rare species at Chrtníky and restricted to sponges. Well-preserved epibionts provide evidence for the relatively rapid burial of this colonized sponge island immediately following the disarticulation of articulated organisms (octocoral, oyster). Another example is represented by the oyster Pycnodonte (Phygraea) vesiculare encrusting the upper surface of a sponge, together with worms of two species, the foraminifer A. nekvasilovae, small oysters, and the bryozoan Onychocella reussi Prantl (Figs 15D-I). A narrowed base is colonized by the worm Cycloserpula gordialis (Schlotheim), an octocoral base (Moltkia) and A. nekvasilovae (Fig. 15I). Moreover, the sponge surface with canal openings was in part overgrown by the hexactinellid sponge Laocoetis vulgata Počta (Fig. 15E). Young specimens of $P$. (P.) vesiculare, A. (A.) reticulata and other epibionts overgrowing the largest $P$. $(P$.) vesiculare indicate long-time encrustation. The attachment of oyster juveniles of varying sizes may correspond with gregarious settlement behaviour (see Knight-Jones 1951). We preliminarily suppose prevailingly post mortem encrustation on both of the above-mentioned benthic sponge islands. However, the thin marginal parts of the large octocoral base of the first of these islands are penetrated by postica of overgrown exhalant sponge surfaces, and may indicate growth on a still living sponge (vital reaction).

Abundant encrustation by small epibionts is also documented by three bryozoan species attached to the sponge Verruculina phillipsi (Fig. 14F), i.e., Stomatopora simplicissima Novák, "Proboscina" sp., and Plagioecia cf. papillosa (Reuss). Good host and epibiont preservation indicates non-abrasive conditions with a low sedimentation rate and rapid final burial. This is documented also by the upper surface of another sponge, overgrown by a large specimen of Hyotissa semiplana, which, after the loss of its upper valve, was overgrown by a new conspecific individual that also lost its upper valve prior to final burial (Fig. 14E). This case of settlement behaviour has nothing in common with gregariousness (see above), because the earliest oyster of this association was already dead at the time of the settling of a new oyster larva, and so could not positively stimulate it. This rare example is rather accidental and may confirm the lack of sufficient substrates on the muddy bottom. The similar orientation of both oyster generations, however, points to long-term stable conditions, i.e., the substrate (sponge) position, water current direction, and a low rate of sedimentation. Small, very well-preserved flat colonies of the bryozoans Plagioecia cf. papillosa and Reptomultelea betusora are scattered over the upper surface of the sponge Scytalia sp. near its osculum (Fig. 14B), while those present on the sponge's side surface are mostly destroyed. A long, slender, poorly preserved bryozoan and a juvenile Pycnodonte $(P$.) vesiculare are also attached near the sponge base. All these epibionts could have settled when the sponge was still alive. Another specimen of this sponge species bears a juvenile Amphidonte (A.) reticulatum retaining an articulated upper valve. The most important aspect of this specimen is the Acruliammina longa that overgrows the commissure between the valves of the oyster, as this might have caused the immobility of right (upper) valve and resulted in its in situ preservation. The sponge Chonella sp. (Fig. 15C) is also encrusted by several epibiont species, among which $A$. nekvasilovae and at least two bryozoan taxa (Onychocella novaki and another indeterminate species) are the most important. In summary, the sponges are remarkably rich in epibionts, which occur on about 50 percent of the larger specimens. It is, however, often very difficult to distinguish between pre- and post-mortem colonization. Only the encrustation of basal attachment surfaces is unambiguous in this respect.

The macrofauna of the claystones-siltstones of the youngest preserved bed $\mathrm{f}$ of unit 8 is taphonomically complex. This bed contains well preserved fragile specimens, e.g., Ancistrocrania? gracilis (Figs 16D, E), the small oysters Amphidonte (A.) reticulatum, Amphidonte (A.) sigmoideum (Reuss) (Figs 16C, J), and Gryphaeostrea canaliculata (see its very thin and fragile upper valve in Fig. 16G), with strongly fragmented bivalves and other

Figure 16. Chrtníky, fauna of unit 8, bed f. • A - thecidean brachiopods Praelacazella lacazelliformis and bryozoan Wilbertopora dilatata attached to the inner surface of fragmentary bivalve shell. $\bullet \mathrm{B}-\mathrm{P}$. lacazelliformis attached to abraded fragment of Ancistrocrania? gracilis valve. $\bullet \mathrm{C}-$ rock sample of bed $\mathrm{f}$ with many fossils (the largest one on the left is Amphidonte (A.) sigmoideum, and beside it is Synhelia gibbosa). $\bullet$ D, E- dorsal valve of brachiopod Ancistrocrania? gracilis, inner and outer views. • F - spine of Tylocidaris vesiculosa with attached juvenile oysters, probably Gryphaeostrea canaliculata. $\bullet \mathrm{G}-$ Gryphaeostrea canaliculata, free valve in external view. $\bullet \mathrm{H}-$ a fragment of phosphatized and silicified stromatolite-like laminated crust (see borings). $\bullet \mathrm{I}-$ a branch of Moltkia foveolata. $\bullet \mathrm{J}$ - oyster Amphidonte (A.) sigmoideum, free valve, external view. $\bullet \mathrm{K}-\mathrm{close}$-up view of internal surface of free shell of $A$. (A.) sigmoideum encrusted by the foraminifer Bullopora $\mathrm{sp} \cdot \bullet \mathrm{L}$ - asteroid ossicle showing high degree of dissolution. $\bullet \mathrm{M}-$ free valve of $A$. (A.) reticulatum with Oichnus isp. (hole drilled by gastropod or other molluscan predator). $\bullet \mathrm{N}-$ Tylocidaris vesiculosa, an interambulacral with adjacent ambulacral plates. Scale bars: A, B, D, E, G-I, L-N $-2 \mathrm{~mm}, \mathrm{C}, \mathrm{F}, \mathrm{J}-5 \mathrm{~mm}, \mathrm{~K}-1 \mathrm{~mm}$. 


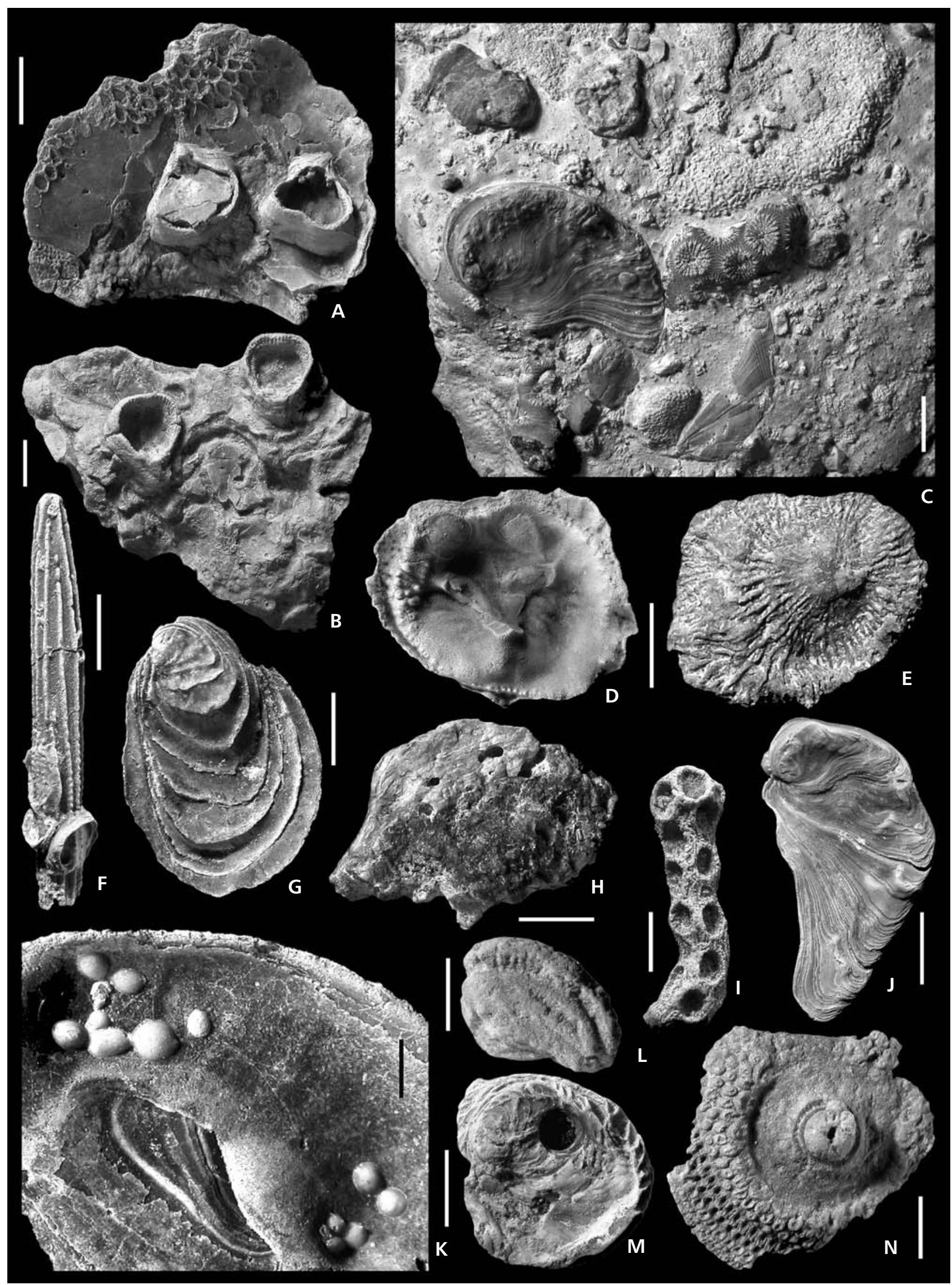


fauna. The fragments may be sharp-edged or with slightly rounded edges (Figs 16A, B, 17I). All articulated bivalve skeletons are disarticulated except one young oyster Amphidonte (A.) reticulatum (Fig. 17K). The ramified branches of bryozoans were mostly fragmented though many longer fragments are preserved, sometimes with their bases (Figs 17A, C, E, H). The bryozoan structure is sometimes well preserved (Figs 17B, D, F, G). Long spines of Tylocidaris vesiculosa are generally completely preserved (Fig. 16F). Interambulacral plates of cidaroid echinoids are mostly complete, isolated (Fig. 170), and bear relics of adjacent ambulacral zones only occasionally (Fig. 16N). Encrustation of bioclasts is frequent [see $G$. canaliculata on echinoid spine-Fig. 16F; Bullopora sp. on inner surface of the free valve of Amphidonte (A.) sigmoideum - Fig. 16K; Pycnodonte (P.) vesiculare and Amphidonte (A.) reticulatum on isolated cidaroid plate Fig. 17O]. The thecideid Praelacazella lacazelliformis encrusting an oyster (Fig. 16A) and Ancistrocrania? (Fig. 16B) fragments were found in several cases. Finds of ?coralline sponges (Gen. et sp. indet.) overgrowing both the preserved bioclasts (Fig. 17I) and an unpreserved, probably soft organic substrate (Fig. 17J) are common. Traces of skeletal dissolution are frequent mainly on echinoid spines with partly removed cortex and on asteroid ossicles (Fig. 16L), the morphology of which may be strongly affected. Traces of boring by Oichnus isp. [holes drilled by gastropod and other molluscan predators, see the upper valve of Amphidonte (A.) reticulatum in Fig. 16M] or the bite marks of durophagous predators on an asteroid ossicle (Fig. 17L), similar to those described by Neumann (2000), are relatively rare. Sponges are quite rare in bed $f$ of unit 8 , but do occur fragmented into small pieces with the skeletal structure well preserved (Fig. 17P). They undoubtedly arose synsedimentarily. Even rarer are small sharp-edged fragments of phosphatized sponges of the same taxa, with completely dissolved skeletal mesh (Fig. 17N). In summary, the taphocoenosis is characterized by the rather high time-averaging of the skeletal remains and a very wide range of individual taphonomic features. The fragmented and abraded or sharp-edged remains, occurring together with complete, perfectly preserved skeletal parts, the frequent encrustations of inner shell surfaces, and the near-complete disarticulation and traces of dissolution indicate long-term processes in a taphonomically active zone involving deeper re-burials, recycling, and mixing of bioclasts. We assume long-term derivation of taphocoenosis with individual components prevailingly transported downslope (in the channel) from the wide bottom areas in a well aerated sea.

The taphonomy of epifauna encrusting the diabase clasts (mostly boulders) and rocky bottom has also provided considerable data on the sedimentary environment and palaeoecology. The well preserved mass occurrence of serpulids (Gen. et sp. indet.) on a boulder from unit 1 shows colonization that was possibly in situ or occurred close to the final burial of the boulder in the channel. The medium-sized oysters [Amphidonte (A.) haliotoideum (Sowerby)] found on a diabase boulder in unit 3 (about 10 specimens) were deprived of their upper valves and more or less abraded. They settled in two groups in a shallow, depressed area of the boulder surface in similar orientations and probably belong to a single spatfall. Unfortunately, the boulder was not found directly within the section, but very close to it. The diabase clasts with corroded surfaces (Fig. 18B) and local relics of post-corrosion phosphatic crusts were colonized in several phases, and in at least two different positions, by the Atreta-Bdelloidina encrusting community (Žítt \& Nekvasilová 1996). Each position is best documented by the slope orientation of the attached bivalves (so-called false oysters) Atreta sp. 1 and sp. 2, which is stable regardless of water currents and other conditions (see Žítt \& Nekvasilová 1994, 1996). The abundant encrusters of these boulders (Fig. 18A), among which the large foraminifer Bdelloidina cribrosa is also very conspicuous, were described by Žítt \& Nekvasilová (1991). The corroded diabase rock elevation (for its location see Fig. 1B) also bears Atreta in stable positions. Several encrustation phases are apparent, and can be distinguished from each other only by overgrowth and preservation. Their abrasion was slight, and the bioerosion and long-term exposure were probably the main destructive factors. The encrustation of this rock and the corroded clasts occurred in the post-corrosion developmental stage in the Chrtníky area, during which the sediments of units 4-8 (bed f) were formed. However, the death of the latest encrusters of every individual boulder must approximately correspond to the age of youngest surrounding and covering sediments. The encrusters of the topmost boulders should correspond to beds $\mathrm{d}$ and e of unit 8 . On the other

Figure 17. Chrtníky, fauna of unit 8 , bed f. • A, B - bryozoan Clausa heteropora, erect colony (A) and detail of structure (B). • C, D - bryozoan Tyloporella reussi, encrusting colony (C) and detail of structure (D). $\bullet$ E - bryozoan Osculipora truncata, delicately branched erect colony. $\bullet$ F - bryozoan Reptomultelea sarthacensis, detail of multilamellar colony. $\bullet \mathrm{G}$ - bryozoan Onychocella novaki, detail of multilamellar colony. $\bullet \mathrm{H}$ - bryozoan Tholopora novaki, robust erect colony. $\bullet \mathrm{I}$ - fragment of Ancistrocrania? gracilis encrusted by indeterminate sponge (Gen. et sp. indet.). $\bullet \mathbf{J}-$ probably the same species originally encrusting a soft, unpreserved organic substrate. $\bullet \mathrm{K}$-juvenile oyster Amphidonte (A.) reticulatum with articulated upper valve. $\bullet \mathrm{L}-$ asteroid ossicle with bite marks. $\bullet \mathrm{M}$ - shark tooth Paranomotodon angustidens. $\bullet \mathrm{N}, \mathrm{P}$ - fragments of hexactinellid sponges; dictyonal skeleton preserved (P) and dissolved during phosphatization $(\mathrm{N}) . \bullet \mathrm{O}-$ abraded interambulacral plate of Tylocidaris cf. vesiculosa encrusted by juvenile oysters. Scale bars: A, C, E, H, I, K, L, N-P - 1 mm, D, G - $100 \mu \mathrm{m}, \mathrm{F}-200 \mu \mathrm{m}, \mathrm{J}, \mathrm{M}-2 \mathrm{~mm}$. 


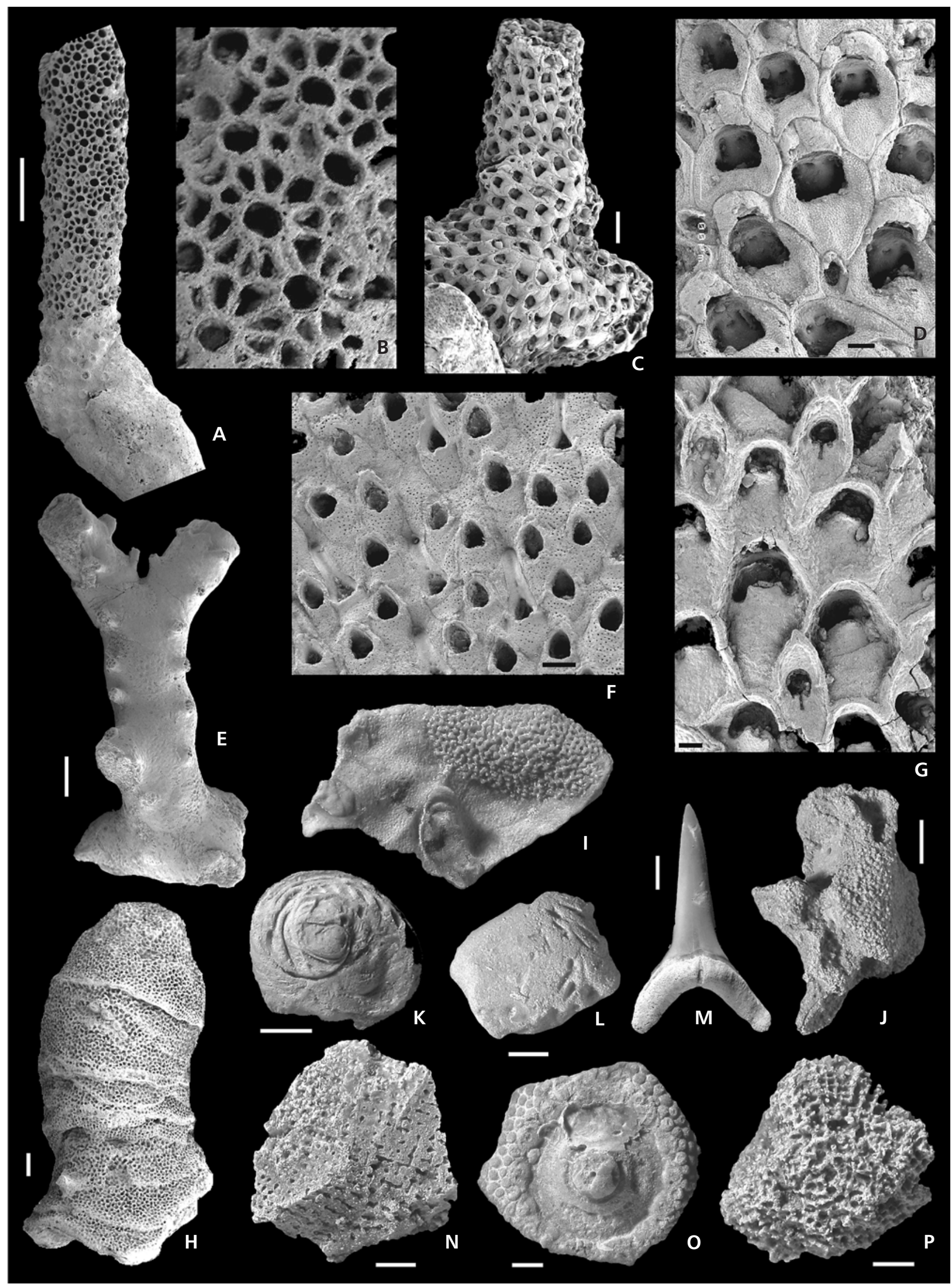


Table 1. Distribution of macrofauna at Chrtníky. For units see Fig. 3.

\begin{tabular}{|c|c|c|c|c|}
\hline \multirow{2}{*}{ Species } & \multicolumn{4}{|c|}{ Units, beds } \\
\hline & 3 & 7 & 8, a-e & $8, \mathrm{f}$ \\
\hline \multicolumn{5}{|l|}{ PORIFERA } \\
\hline Astrobolia conglobata (Reuss) & & & + & \\
\hline Astrobolia plauensis (Geinitz) & & & + & \\
\hline Astrocladia sp. & & & + & \\
\hline Botroclonium arborescens Počta & & & + & + \\
\hline Chonella cf. patella Počta & & & + & \\
\hline Chonella sp. & & & + & + \\
\hline Cytoracia obesa (Počta) & & & + & + \\
\hline Cystispongia morchella (Reuss) & & & + & + \\
\hline Diplodictyon heteromorphum (Reuss) & & & + & + \\
\hline Endostoma sp. & & & + & \\
\hline Guettardiscyphia sp. & & & + & + \\
\hline Jerea decurtata Počta & & & + & \\
\hline Laocoetis beaumonti (Reuss) & & & + & \\
\hline Laocoetis vulgata (Počta) & & & + & + \\
\hline Lychniscosida Gen. et sp. indet. & & & + & \\
\hline Pachytilodia bohemica Počta & & + & & \\
\hline Scytalia pertusa (Reuss) & & & + & \\
\hline Scytalia sp. & & & + & \\
\hline Seliscothon sp. & & & + & \\
\hline Siphonia geinitzi Zittel & & & + & + \\
\hline Siphonia sp. & & & + & \\
\hline Tremospongia clavata (Počta) & & & + & \\
\hline Verrucospongia sparsa (Reuss) & & & + & \\
\hline Verruculina phillipsi (Reuss) & & & + & + \\
\hline Verruculina sp. & & + & & \\
\hline Gen. et sp. indet. & & & + & + \\
\hline
\end{tabular}

\begin{tabular}{llll} 
COELENTERATA & & & \\
Anthophyllum cylindricum (Reuss) & + & + & + \\
coral Gen. et sp. indet. & & + & \\
Moltkia foveolata (Reuss) & + & + & + \\
Synhelia gibbosa (Goldfuss) & + & + & + \\
Trochosmilia sp. & & + & + \\
\hline
\end{tabular}

\begin{tabular}{|c|c|c|c|c|}
\hline Trochosmilia sp. & & & + & + \\
\hline "VERMES" & & & & \\
\hline Cycloserpula gordialis (Schlotheim) & & + & + & + \\
\hline Mucroserpula sp. & & & + & \\
\hline $\begin{array}{l}\text { Neomicrorbis crenatostriatus } \\
\text { subrugosus (Münster) }\end{array}$ & + & + & + & \\
\hline Pomatoceros sp. & & + & + & \\
\hline Serpula cf. rauca Ziegler & + & & & \\
\hline serpulid Gen. et sp. indet. & & & & \\
\hline ?Spiraserpula spirographis (Goldfuss) & & & + & \\
\hline BRYOZOA & & & & \\
\hline Clausa heteropora d'Orbigny & & & & + \\
\hline Desmepora plebeia Novák & & & & + \\
\hline Diastopora sp. & & & & + \\
\hline
\end{tabular}

\begin{tabular}{|c|c|c|c|c|c|}
\hline \multirow{2}{*}{ Species } & \multicolumn{5}{|c|}{ Units, beds } \\
\hline & 1 & 3 & 7 & $8, \mathrm{a}-\mathrm{e}$ & $8, \mathrm{f}$ \\
\hline \multicolumn{5}{|l|}{ Latereschara achates d'Orbigny } & + \\
\hline \multicolumn{3}{|l|}{ Marginaria elliptica Roemer } & + & + & \\
\hline \multicolumn{3}{|c|}{ Mecynoecia madreporacea (Goldfuss) } & & & + \\
\hline \multicolumn{3}{|l|}{ Onychocella novaki (Brydone) } & & + & + \\
\hline \multicolumn{3}{|l|}{ Onychocella reussi Prantl } & & + & + \\
\hline \multicolumn{3}{|l|}{ Osculipora truncata (Goldfuss) } & & & + \\
\hline \multicolumn{3}{|l|}{ Plagioecia cf. papillosa (Reuss) } & + & + & \\
\hline \multicolumn{3}{|l|}{ Polyceratophora euglypha (Novák) } & + & $?$ & \\
\hline \multicolumn{3}{|l|}{ "Proboscina" sp. } & + & + & \\
\hline \multicolumn{3}{|l|}{ Reptomultelea betusora Taylor } & & + & + \\
\hline \multicolumn{3}{|l|}{ Reptomultelea reussi (Pergens) } & + & & \\
\hline \multicolumn{3}{|c|}{ Reptomultelea sarthacensis (d'Orbigny) } & + & + & + \\
\hline \multicolumn{3}{|c|}{ Reptomultelea tuberculata (d'Orbigny) } & + & & \\
\hline \multicolumn{3}{|l|}{ Stomatopora simplicissima Novák } & + & + & \\
\hline \multicolumn{3}{|l|}{ Tholopora novaki (Gregory) } & & & + \\
\hline \multicolumn{3}{|l|}{ Tyloporella reussi Voigt } & & + & + \\
\hline \multicolumn{3}{|l|}{ Voigtopora calypso (d'Orbigny) } & + & & \\
\hline \multicolumn{3}{|l|}{ Wilbertopora dilatata (Reuss) } & & + & + \\
\hline \multicolumn{6}{|l|}{ BRACHIOPODA } \\
\hline \multicolumn{3}{|l|}{ Ancistrocrania? gracilis (Münster) } & + & + & + \\
\hline \multicolumn{2}{|l|}{ Cyclothyris zahalkai Nekvasilová } & + & + & + & + \\
\hline Gisilina? rudolphi (Geinitz) & + & & & & \\
\hline Praelacazella lacazelliformis (El & iot) & & + & + & + \\
\hline Terebratula? "biplicata" Sowerb & & + & + & & \\
\hline Terebratulina "chrysalis" (Schlo & theim) & & + & & + \\
\hline MOLLUSCA - Bivalvia & & & & & \\
\hline $\begin{array}{l}\text { Amphidonte (Amphidonte) } \\
\text { haliotoideum (Sowerby) }\end{array}$ & & + & & & \\
\hline Amphidonte (A.) reticulatum $(\mathrm{Re}$ & Iss) & & + & + & + \\
\hline Amphidonte (A.) sigmoideum ( $\mathrm{Re}$ & uss) & & $?$ & + & + \\
\hline Atreta sp. 1 & & & & + & \\
\hline Atreta sp. 2 & & & & + & \\
\hline Chlamys sp. & & & & + & \\
\hline Gryphaeostrea canaliculata (Sov & erby) & & + & + & + \\
\hline Hyotissa semiplana (Sowerby) & & & + & + & + \\
\hline Inoceramus ex gr. labiatus (Schl & theim) & & + & & \\
\hline Lima sp. & & & + & & \\
\hline Neithea sp. & & + & & & \\
\hline Ostrea cf. operculata Reuss & + & + & + & & \\
\hline oyster Gen. et sp. indet. & + & & & & \\
\hline Pinna sp. & & & & + & \\
\hline Plicatula inflata Sowerby & & & & & + \\
\hline Pycnodonte (Phygraea) vesicula & $e(\mathrm{Lam}$ & arck) & & + & + \\
\hline Rastellum carinatum (Lamarck) & & + & & & \\
\hline Rastellum diluvianum (Linné) & + & + & & & \\
\hline Septifer lineatus (d'Orbigny) & & & & & + \\
\hline
\end{tabular}




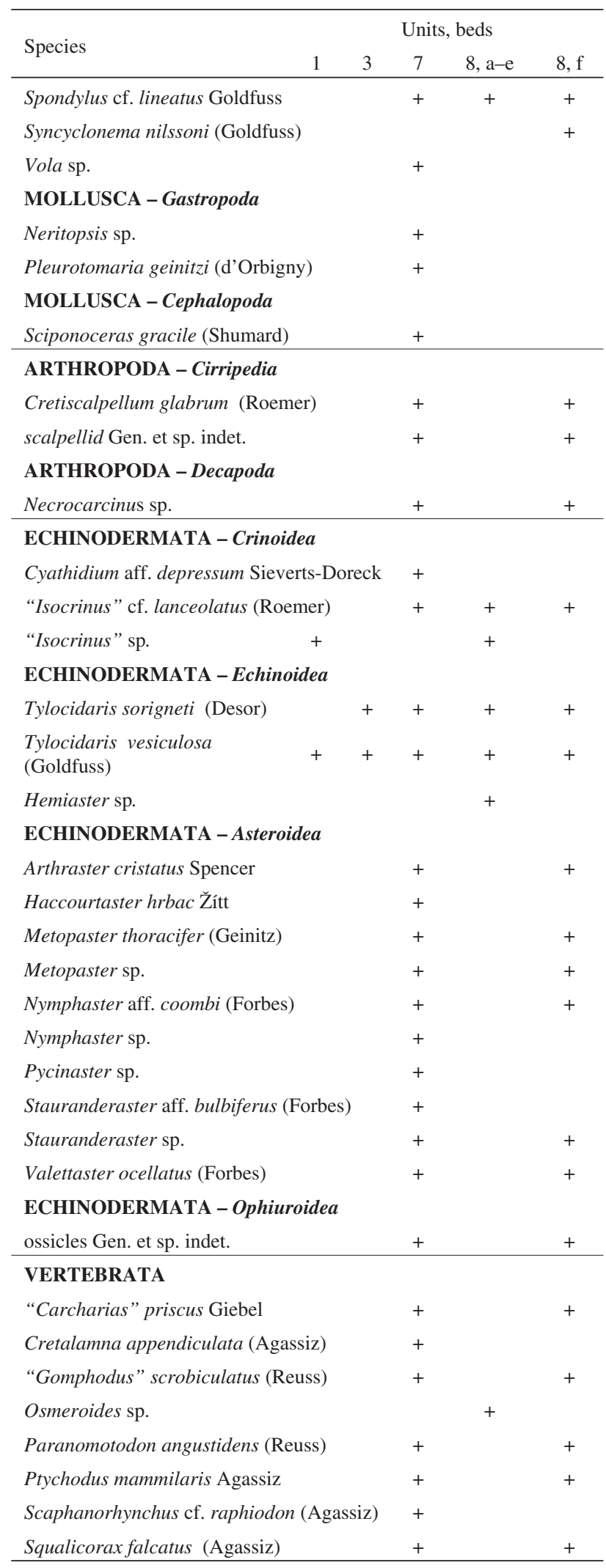
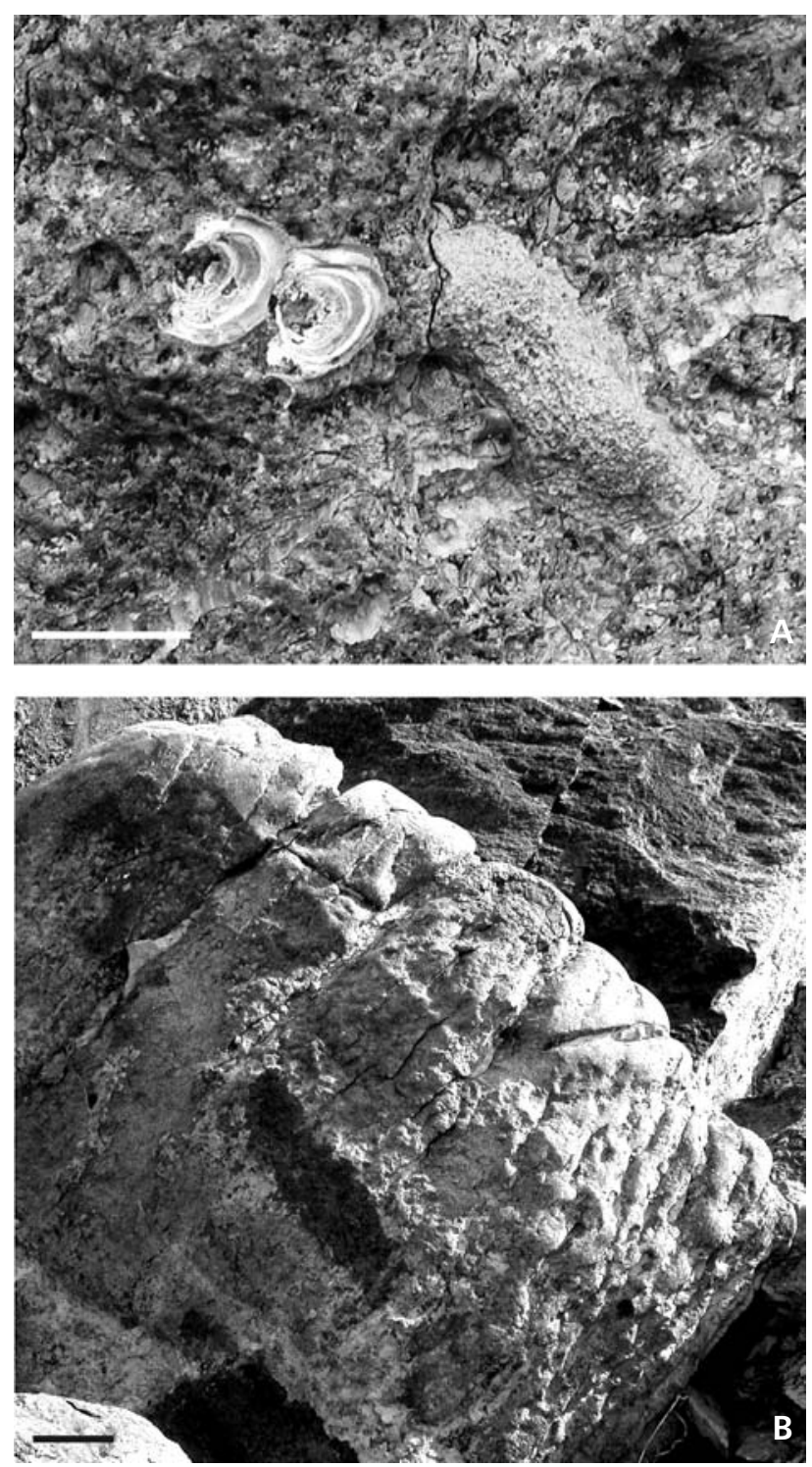

Figure 18. Chrtníky, unit 8. - A - part of a corroded diabase boulder with attached bivalve Atreta sp. 2 (in slope orientation) and a lithistid sponge. $-\mathrm{B}-\mathrm{a}$ diabase boulder with corroded surface and accentuated rock fabric. Scale bars: A $-10 \mathrm{~mm}, \mathrm{~B}-20 \mathrm{~cm}$.

hand, the colonization of the diabase rock elevation could theoretically cover a longer time interval, because it was elevated even above the base of bed $f$ of unit 8 . The problem is, however, even more complex; for although the identically preserved encrusters of the whole rock surface seem to be synchronous, this is not necessarily the case. The rock certainly was not buried abruptly. The sedimentation rates were variable, but based on the survival of some epibiont sponge islands (e.g., that on Fig. 14A), it could not have exceeded a few millimetres per year in some time intervals. There existed, however, intervals of more rapid sedimentation during which large masses of sponges were accumulated together with probably redeposited muddy sediments. 


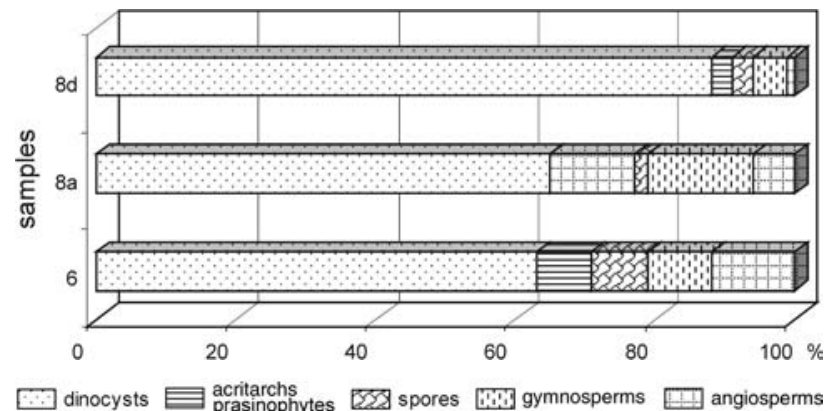

Figure 19. Histogram showing distribution of palynomorph taxa in three successive samples of the Lower Turonian. The numbers of samples are identical to those of units and beds (see Fig. 3).

The complete burial of the highest part of the rock, about 4 metres high, is estimated to have taken at least one thousand (if not several thousand) years. The sediment-free area of the rock slowly decreased, but colonization thereon continued simultaneously with destructive processes. The resulting picture of the simultaneous colonization of the whole rock is thus only apparent, and the actual course of the process is obscured. The earliest encrusters, the remains of which could theoretically increase in number upwards, were not identified as such. Poorly preserved remains were not found to be more numerous here when compared with the base of the rock. The relatively rapid post-mortem disappearance of epibiont remains thus seems to be proved. We estimate that the total duration of encrustation did not much exceed the deposition of bed $f$ of unit 8. The taxonomic composition of the encrusting community did not change during this time.

\section{Micropalaeontology}

\section{Palynology}

All studied samples come from the Giant Channel. The sample numbers agree with those of the distinguished units (Fig. 3). For a list of species see Table 2.

Seven samples, each from a different lithology and stratigraphic horizon, were studied, only five of which yielded palynologic results. Two samples (units 1 and 4) were very poor, but another three (units 6 and 8 - beds a, d) contained organic-walled microfossils (Fig. 20, Table 2). Marine influence in samples 4, 6, and 7 is documented by the presence of dinocysts, acritarchs, and the faunal remains of chitinous foraminiferal linings and scolecodonts (jaws of worms of the Annelida-Polychaeta type). Dinoflagellate cysts prevail (63-88 \%, Fig. 19). The spore-pollen flora is not diverse and consists mostly of thick-walled forms, i.e., pteridophyte spores of Gleicheniidites, Cicatricosisporites, Deltoidospora, and triporate angiosperm pollen Complexiopollis, Atlantopollis.
Sample 1.-Dark grey calcareous sandstone contained only black particles of inertinite. Preservation of this matter indicates a high degree of degradation and maturity in lithologically unfavourable sediment. The presence of vitrinite and absence of organic-walled microfossils seem to be connected to the extreme conditions accompanying the beginning of the interval of condensed sedimentation and subsequent phosphogenesis in the top parts of unit 1. In addition to the vitrinite, only very rare spores of Pluricellaesporites sp. (Fungi imperfecti) were found.

Sample 4. - The stromatolite build-up comprising both the phosphatized light limestone and the greenish claystone laminae contained minor vitrinite and very rare, poorly preserved gymnosperm pollen grains of Cycadopites sp. Some extreme conditions unfavourable for the preservation of a wider spectrum of palynomorphs could resemble those of the above-mentioned sample from unit 1 .

Sample 6. - A relatively well-preserved assemblage is dominated by the dinocyst species Palaeohystrichophora infusorioides. Other dinoflagellate cysts constitute a mixture of the neritic species Achomosphaera ramulifera, Florentinia laciniata, Hystrichodinium pulchrum, Surculosphaeridium longifurcatum, and Oligosphaeridium complex, and shallow-marine elements such as Odontochitina operculata, Cribroperidinium sp. Due to the dominance of Palaeohystrichophora infusorioides, and the presence of chitinous foraminiferal linings, a shallow marine environment is assumed.

Studied palynological assemblages are dominated by dinocysts and acritarchs belonging to micrhystrids and veryhachids. The spore-pollen assemblage is not well preserved. A strong terrestrial influence is documented by numerous woody phytoclasts, dark brown to black in colour. The presence of pteridophyte and bryophyte spores, as well as the gymnosperm species Corollina torosa (Cheirolepidiaceae) and Taxodiaceaepollenites hiatus, indicates marsh vegetation.

The biostratigraphically important triporate Normapolles genera Complexiopollis praeatumescens, Complexiopollis turonis, and Atlantopollis verrucosus indicate an Early Turonian age. The composition of the Normapolles genera is similar to assemblages described from other localities, e.g., Velim (Žítt et al. 1997), Markovice, and Karlov (Žítt et al. 2001). Dinoflagellate cysts comprise long-ranging species found in Upper Cenomanian and Lower Turonian deposits.

Samples $8 a$ and $8 d$. - Despite the similar palynological composition characterizing the prevalence of dinocysts and the dominance of Palaeohystrichophora infusorioides, the terrestrial input markedly decreases. The influence of deeper-sea conditions is evidenced by presence of Pterodi- 
nium cingulatum. The preservation of all microfossil elements is very poor; they are often pale yellow and strongly corroded.

The palynofacies are characterized by dinocysts, rare spores, and triporate angiosperm pollen. Wind-transported bisaccate pollen of Pinaceae is relatively abundant. The amount of woody particles decreases, while the finely granular, unstructured masses of amorphous organic matter with rare faecal pellets increases. The composition of palynomorph assemblage and palynofacies character indicates the gradual deepening of a marine environment during sedimentation of the uppermost preserved Lower Turonian strata.

\section{Foraminifera}

All the samples come from the Giant Channel. The sample numbers correspond to those of the distinguished units (Fig. 3). The basal sandy matrix of unit 1 was unfortunately completely barren. They could be studied only as high as the Lower Turonian strata, from which only units 5, 7, and 8 (beds a, b, d, f) could be wet screened. For a list of species see Table 3 .

Sample 5. - This sample comes from highly weathered limestone. The sample yielded a low-diversity association of mostly stratigraphically insignificant species. The most important species, Lingulogavelinella globosa (Brotzen) and Gavelinella belorussica (Akimec), are known from the uppermost Cenomanian, becoming extinct in the Lower Turonian (Hradecká 1996). The agglutinated species Haplophragmoides nonioninoides (Reuss) occurs only in this sample. Together with the non-Cenomanian species Frondicularia verneuiliana d'Orbigny (TuronianSantonian in the BCB, see Hercogová 1978), they indicate an Early Turonian rather than a Late Cenomanian date for this sample.

Sample 7. - This sample is characterised by the appearance of Cassidella tegulata (Reuss) (Lower-Middle Turonian) and minute tests of Tappannina eouvigeriniformis (Keller). The species Gavelinella belorussica and

Table 2. Distribution of palynomorphs at Chrtníky. For location of units (samples) see Fig. 3. Explanations: $*=1$ specimen, $* *=2-10, * * *=11-20, * * * * *$ more than 60

\begin{tabular}{|c|c|c|c|}
\hline \multirow{2}{*}{ Species } & \multicolumn{3}{|c|}{ Units, beds } \\
\hline & 6 & $8, \mathrm{a}$ & $8, \mathrm{~d}$ \\
\hline \multicolumn{4}{|l|}{ Dinoflagellate cysts } \\
\hline Achomosphaera ramulifera (Eisenack) Davey \& Williams & $* *$ & & $* *$ \\
\hline Cleistosphaeridium spp. & $* *$ & $*$ & \\
\hline Coronifera oceanica Cookson \& Eisenack & $*$ & & \\
\hline Cribroperidinium sp. & & & $*$ \\
\hline Exochosphaeridium bifidum (Clarke \& Verdier) & $*$ & & \\
\hline Florentinia cf. laciniata Davey \& Verdier & $*$ & & \\
\hline Hystrichodinium pulchrum Deflandre & $*$ & & $*$ \\
\hline Hystrichostrogylon membraniphorum Agelopoulos & & & * \\
\hline Microdinium ornatum Cookson \& Eisenack & $*$ & & \\
\hline Odontochitina operculata (O. Wetzel) Deflandre \& Cookson & $*$ & & $*$ \\
\hline Oligosphaeridium complex (White) Davey \& Williams & $*$ & & $*$ \\
\hline Palaeohystrichophora infusorioides Deflandre & $* * * * *$ & $* *$ & $* * * * *$ \\
\hline Psaligonyaulax deflandrei Sarjeant in Davey et al. & & & $*$ \\
\hline Pterodinium cingulatum (O. Wetzel) Below & & & $*$ \\
\hline Spiniferites ramosus (Ehrenberg) Loeblich \& Loeblich & $* *$ & & $* *$ \\
\hline Subtilisphaera sp. & $* *$ & $*$ & \\
\hline ?Surculosphaeridium longifurcatum (Firtion) Davey et al. & & & $* *$ \\
\hline Stephodinium coronatum Deflandre & & & $*$ \\
\hline Trichodinium castanea (Deflandre) Clarke \& Verdier & $*$ & & \\
\hline Wallodinium luna (Cookson \& Eisenack) Lentin \& Williams & & & $*$ \\
\hline Xenascus ceratioides (Deflandre) Lentin \& Williams & $*$ & & \\
\hline
\end{tabular}

\begin{tabular}{|c|c|c|c|}
\hline \multicolumn{4}{|l|}{ Acritarchs and prasinophytes } \\
\hline Cymatiosphaera costata Davey & $*$ & $* *$ & $*$ \\
\hline Micrhystridium spp. & $* *$ & $*$ & * \\
\hline Pterospermella helios Sarjeant & $* *$ & & \\
\hline Tasmanites sp. & $*$ & & \\
\hline Veryhachium spp. & $* *$ & & \\
\hline
\end{tabular}

Bryophyte and pteridophyte spores

Cicatricosisporites venustus Deák

Cicatricososporites sp.

Cingutriletes clavus (Balme) Dettmann

Deltoidospora minor (Balme) Dettmann

Gleicheniidites circinidites Cookson

Gleicheniidites senonicus Ross

\section{Gymnosperm pollen}

Corollina torosa (Reissinger) Klaus emend. Cornet \& Traverse

Cycadopites sp.

Pinuspollenites sp.

Taxodiaceaepollenites hiatus (Potonié) Kremp

Angiosperm pollen

Atlantopollis sp.

Complexiopollis praeatumescens Krutzsch

Complexiopollis turonis Krutzsch

Complexiopollis vulgaris Krutzsch

Complexiopollis spp.

$*$

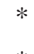

$\begin{array}{lll} & * & \\ * & & \\ * & & \\ * * & & *\end{array}$

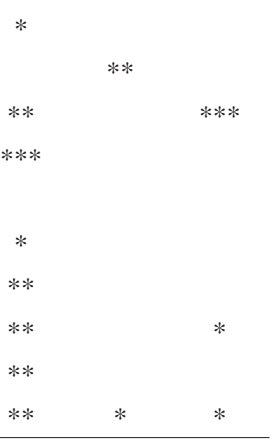

Faunal remains

scolecodonts 
Lingulogavelinella pazdroae Gawor-Biedowa (Upper Cenomanian-Lower Turonian in the BCB) are common here but absent in the overlying beds. Planktonic species are generally more abundant, indicating a deepening of the sea relative to unit 5. This sample belongs to the Helvetoglobotruncana helvetica Zone (in the sense of Robaszynski \& Caron 1995) of Early Turonian age.

Samples $8 a, b, d, f$. - These samples are characterized by Frondicularia and common plankton (especially in sample 8d) with keeled forms such as Dicarinella and Praeglobotruncana. Whiteinella brittonensis Loeblich \& Tappan is also common. The topmost sample 8f shows the highest diversity of all (24 species). For instance, Lenticulina and Gaudryina (with the first occurrence of G. folium Akimec) are very abundant. In general, the composition of the foraminiferal association of unit 8 , beds $\mathrm{d}$ and $\mathrm{f}$, indicates a deepening and transition to an open sea-environment.

\section{Oldest Cretaceous sediments of the Chrtníky area and phosphatic intraclasts}

Phosphatic intraclasts occur abundantly in the deposits of units 3 and 7 of the GC. These intraclasts consist not only of various remains of macrofauna (mainly sponges, oysters, and large foraminifera), including phosphatized casts of Sciponoceras gracile (Fig. 21I), but also of fragments of phosphatized sediments, sometimes slightly abraded (Figs 21A-C). The affection of the surface parts of the ancient source sediment to strong phosphogenesis is therefore clearly documented. The intraclasts of phosphatized sediment show the lithology of the original mineralized deposits, among which siltstones and more restricted sandstones were predominant. A correlation between the deposition of these sediments and their subsequent mineralization phase with any of the above-mentioned lithologies at Chrtníky is, however, impossible. The earliest preserved deposits at Chrtníky (unit 1, lower conglomerates) are approximately dated as the boundary interval Rotalipora cushmani - Praeactinocamax plenus zones (upper part of Metoicoceras geslinanum Zone, Upper Cenomanian) when compared to Předboj near Prague. The original deposits with Sciponoceras at Chrtníky and their phosphatization are probably older (lower part of Metoicoceras geslinianum Zone, Upper Cenomanian). The lit- hology of the phosphatized rock fragments indicates that the marly sedimentation of this interval probably represents offshore sedimentation relative to the unpreserved coarse clastic facies. In these sediments a rise in sea level and a concurrent decrease in sedimentation rate could have enabled the phosphatization processes. The phosphogenesis related to this earliest sedimentary period in the Chrtníky area may have been coeval with that at Předboj, documented by phosphatic products that were redeposited during the boundary interval Rotalipora cushmani - Praeactinocamax plenus zones (Žítt et al. 1999; Žítt \& Mikuláš in press). However, the destruction of the coeval deposits at Chrtníky occurred later, first during an advanced transgression recorded by the youngest conglomerates of unit 3, and then again during the sedimentation of unit 7. During these reworking episodes the oldest Cretaceous marine sediments were completely removed from the Chrtníky area.

\section{Palaeoenvironments}

Note: Numbers of individual palaeoenvironmental steps correspond to the numbers of the above described units $1-8$.

\section{Step 1. Abrasion and conglomerates}

The abrasion-erosion palaeoenvironmental stage undoubtedly strongly changed the surface of the Chrtníky diabase massif. In the flooded zone, all older Cretaceous deposits and pre-transgression weathering products were destroyed and reworked. The rocky bottom channels and depressions of the preceding sedimentation episodes were possibly vacated in exposed zones, and new ones gradually arose in places of weakened rock resistance (crevices, tectonics). The prolonged abrasion period is recorded by the thick accumulations of perfectly rounded rock clasts and the sandy matrix of conglomerates. However, the deposition of clastics directly onto the steep bottoms of channels is a little younger, and records a sea-level rise and the decline from extreme shallow-water conditions in the bottom zone of the studied sections. It follows that the clastics of these sections originated a short distance shorewards in an area which, considering the steep rocky shoreface, was practically adjacent to the newly flooded higher parts of the

Figure 20. Chrtníky, palynomorphs and scolecodonts (samples correspond to units and beds). - Dinoflagellate cysts: A - ?Surculosphaeridium longifurcatum (sample 8, bed a). B - Microdinium ornatum (sample 6). C - Palaeohystrichophora infusorioides (sample 6). D - Cribroperidinium sp. (sample 8, bed a). E - Pterodinium cingulatum ssp. cingulatum (sample 8, bed a). - Pteridophyta: F - Gleicheniidites circinidites (sample 6). - Prasinophyta: G - Pterospermella sp. (sample 6). - Scolecodonts: H, I (sample 6). - Gymnospermophyta: J - Classopollis classoides (sample 6). - Angiospermophyta: K - Complexiopollis cf. turonis (sample 6). L - Complexiopollis praeatumescens (sample 6). Scale bars represent 10 um. 

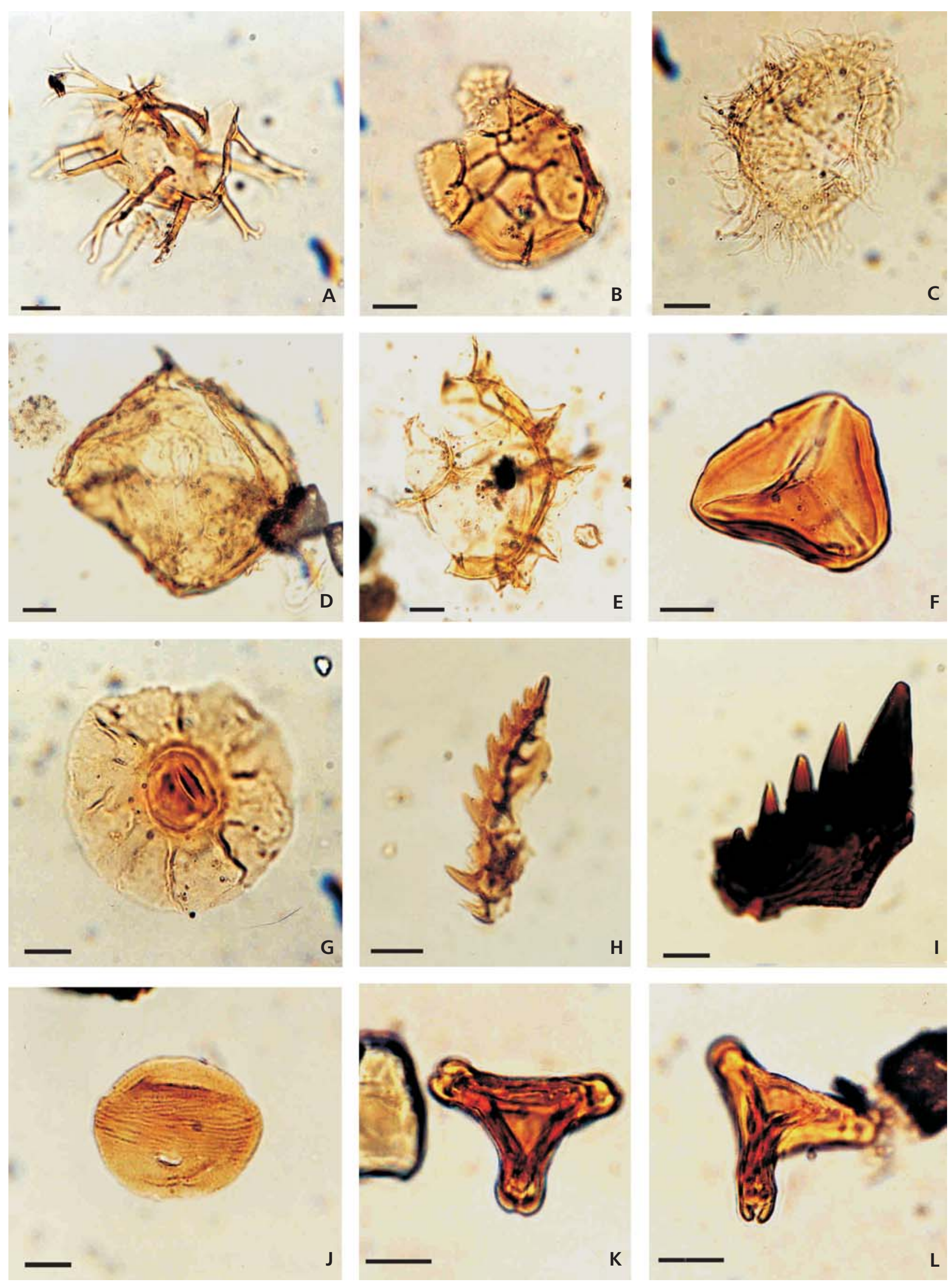
rocky coast. The Giant Channel, which was by that time free of any deposits and served only for their seaward transport, is where the sedimentation of clastics could have started. The unsorted nature of clastics indicates limited transport and the possible role of environmental stress (such as seasonal weather reversals and storms). Although the arrangement and roundness of the diabase clasts in the conglomerate is more or less uniform upwards, the matrix and macrofauna reflect the continued rise of sea level. The decreasing amount of sand grains and increasing proportion of carbonate, along with the increasing size and degree of preservation of the bioclasts, indicate a decreasing supply of remains from agitated waters and/or an increasing proportion of autochthonous organisms.

\section{Step 2. Lower condensation interval}

Under the above-mentioned conditions, the deposition of the conglomerate matrix was not cut by a sharp erosion surface, but rather by an irregularly washed out surface of partially lithified sediment. Organic matter enrichment of the topmost matrix seems to indicate the beginning of sedimentary stagnation, the absence of clastic sedimentary input, and the depletion of oxygen in the bottom strata. These conditions may best be explained by a relatively rapid environmental change. However, with respect to the future rapid renewal of the pre-condensation conditions (see the step 3), a slightly exceeded environmental threshold, such as a certain depth, could have been responsible. The fall in the amount of sand may demonstrate the complete submergence of all rock elevations (islands) below the storm wave base, together with a corresponding shift of the shoreline. The following development nevertheless indicates long-term, unstable conditions probably caused by slightly fluctuating depths. The recurrent conditions
Table 3. Distribution of foraminifera at Chrtníky. For location of units (samples) see Fig. 3. Explanation: *** - most abundant, **-abundant, *-rare

\begin{tabular}{|c|c|c|c|c|c|c|}
\hline \multirow{4}{*}{ Species } & \multicolumn{6}{|c|}{ Lower Turonian } \\
\hline & $\begin{array}{l}\text { W. arch. } \\
\text { Zone? }\end{array}$ & \multicolumn{5}{|c|}{$\begin{array}{l}\text { Helvetoglobotruncana helvetica } \\
\text { Zone }\end{array}$} \\
\hline & \multicolumn{6}{|c|}{ Units, beds } \\
\hline & 5 & 7 & 8 , a & $8, \mathrm{~b}$ & $8, d$ & $8, \mathrm{f}$ \\
\hline \multicolumn{7}{|l|}{ Agglutinated benthos } \\
\hline Acruliammina longa (Tappan) & & $*$ & $*$ & $*$ & * & $*$ \\
\hline Acruliammina nekvasilovae Hercogová & & & & $*$ & & \\
\hline Arenobulimina intermedia (Reuss) & & & $*$ & & & \\
\hline Arenobulimina preslii (Reuss) & $*$ & $*$ & $*$ & & $*$ & $*$ \\
\hline Arenobulimina sp. & & & & $*$ & $*$ & \\
\hline Ataxophragmium depressum (Perner) & $*$ & $* *$ & $*$ & * & & $*$ \\
\hline Bdelloidina cribrosa (Reuss) & & $*$ & $*$ & $*$ & $*$ & $*$ \\
\hline Gaudryina folium Akimec & & & & & & $*$ \\
\hline Gaudryina praepyramidata Hercogová & & & $*$ & & & \\
\hline Gaudryina trochus (d'Orbigny) & & $*$ & & & & $* *$ \\
\hline Gyroidina nitida (Reuss) & & $*$ & $*$ & $*$ & * & $* *$ \\
\hline Haplophragmoides nonioninoides (Reuss) & $*$ & & & & & \\
\hline Spiroplectinata sp. & & & & & & $*$ \\
\hline
\end{tabular}

\section{Calcareous benthos}

Bullopora sp.

Cassidella tegulata (Reuss)

Dentalina legumen? Reuss

Frondicularia fritschi Perner

Frondicularia intermittens Reuss

Frondicularia verneuiliana d'Orbigny

Gavelinella belorussica (Akimec)

Gavelinella berthelini (Keller)

Gavelinella polessica Akimec

Gavelinella schloenbachi (Reuss)

Gavelinella sp.

Lenticulina comptoni (Sowerby)

Lenticulina sp.

Lingulogavelinella globosa (Brotzen)

Lingulogavelinella pazdroae Gawor-Biedowa

Nodosaria sp.

Praebulimina crebra Štemproková

Quadrimorphina allomorphinoides (Reuss)

Ramulina globulifera Brady

Tappannina eouvigeriniformis (Keller)

Valvulineria lenticula (Reuss)

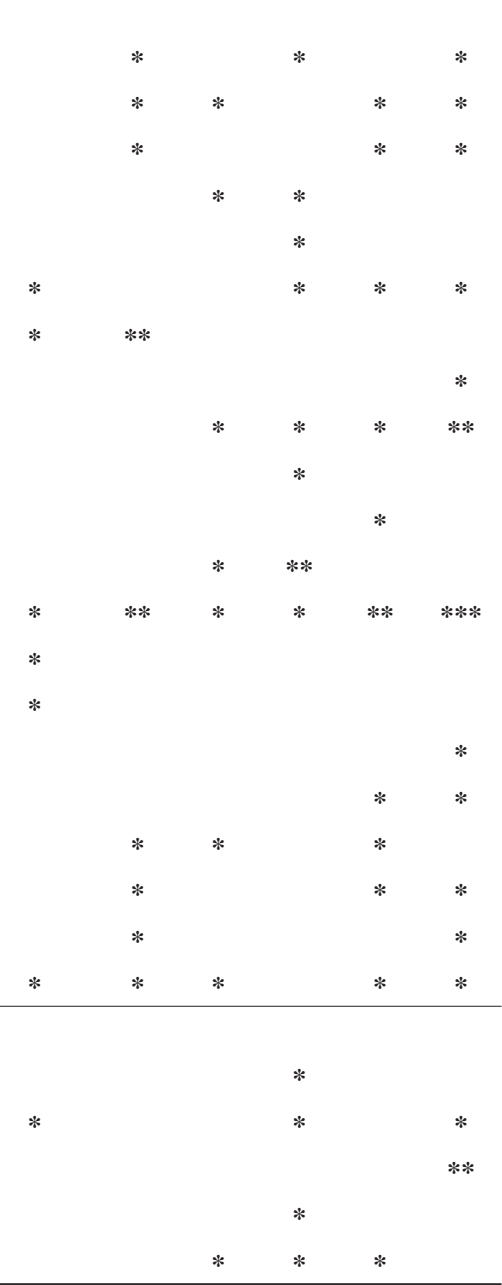


Table 3, continued

\begin{tabular}{|c|c|c|c|c|c|c|}
\hline \multirow{4}{*}{ Species } & \multicolumn{6}{|c|}{ Lower Turonian } \\
\hline & $\begin{array}{l}\text { W. arch. } \\
\text { Zone? }\end{array}$ & \multicolumn{5}{|c|}{$\begin{array}{c}\text { Helvetoglobotruncana helvetica } \\
\text { Zone }\end{array}$} \\
\hline & \multicolumn{6}{|c|}{ Units, beds } \\
\hline & 5 & 7 & 8, a & $8, \mathrm{~b}$ & $8, \mathrm{~d}$ & $8, \mathrm{f}$ \\
\hline Helvetoglobotruncana praehelvetica (Trujillo) & & & $*$ & $* *$ & $*$ & $*$ \\
\hline Heterohelix globulosa (Ehrenberg) & $*$ & & & & $*$ & \\
\hline Praeglobotruncana delrioensis (Plummer) & & & & $*$ & & \\
\hline Praeglobotruncana oraviensis Scheibnerova & & & & $*$ & & \\
\hline Praeglobotruncana turbinata (Reichel) & $*$ & & & & & \\
\hline Whiteinella aprica (Loeblich \& Tappan) & & & & & $*$ & $*$ \\
\hline Whiteinella archaeocretacea Pessagno & $*$ & & $*$ & & $*$ & $*$ \\
\hline Whiteinella baltica Douglas \& Rankin & $*$ & & & & $* *$ & $*$ \\
\hline Whiteinella brittonensis (Loeblich \& Tappan) & $*$ & & $* *$ & $* * *$ & $* * *$ & $* * *$ \\
\hline Whiteinella paradubia (Sigal) & & & $*$ & & & \\
\hline
\end{tabular}

ditions continued with the formation of a new conglomerate generation. However, we postulate only minor in situ abrasion and a downslope redeposition of clasts from a shallower, nearby, landward area. The clasts, though of the same abrasion degree, frequently have variegated surfaces (greenish, red, brown), which possibly indicates the conditions in the places of their previous deposition. The reddish basal bioclastic sediment could have been transported together with the clasts, as it appears to be pressed into the deposits of the condensation interval. However, the input of calcareous bioclastic sediments did not cease, even if the sedimentary environment was gradually changing. The conditions of basal mat-

of soft sediment input and phosphatization, complemented by incursions of grey calcareous muds (later limestone) with many large bioclasts, may be considered typical of this environment. The development of thin laminated phosphatic crusts terminating very locally the phosphogenic episodes, clearly indicates a bloom of microbial populations. The overlying green clay coatings showing the actual shapes of the phosphatized deposits as elevated domes probably arose during periods in which no sediment could have been derived from the landward, but flooded and strongly weathered, diabases. A preliminary study (phase identification based on x-ray powder diffraction) shows the presence of nontronite instead of the supposed glauconite in these greenish coatings. The shapes of the erosion surface on the top of the condensation interval indicate a firmground formed on the grey muds of the bottom, which were not yet fully lithified. The post-erosional influx of clasts and bioclastic calcareous muds (see step 3 ) on this surface was possibly abrupt, and relatively fine sediment penetrated the still partly empty spaces below some large shell fragments within the grey firmground.

\section{Step 3. Re-entry of conglomerate}

The variable plastic deformation of the previously eroded condensation interval deposits by the weight and force of the overlying clasts indicates that there was too short an interval for them to be completely lithified. We cannot, therefore, assume any prominent sea-level change, except for a rapid but small-scale shallowing. The deposits of the condensation interval certainly formed in the topmost parts of the conglomerate-free interstices. Erosion of the top firmground as a result of the return to pre-condensation con- rix sedimentation could well resemble those of the top parts of the preceding conglomerate deposition (yet prior to the pronounced sea level rise, and the decline of sedimentation rate). The conspicuous increase of small suboval to subangular diabase clasts (pebbles and small cobbles) with coloured, chemically altered surfaces, the remains of well-preserved macrofauna, and the presence of phosphatic intraclasts in the top parts of conglomerate most likely indicate a further sea-level rise with the concurrent destruction of sediments of the preceding cycle. A gradual decrease in sediment supply can be assumed for this period.

\section{Step 4. Upper condensation interval}

As a result of the following sea level fall, the top portions of the partly lithified clastic deposits (i.e. their matrix) were eroded (see $\mathrm{e}_{2}$ in Fig. 3B) either by slight sediment scouring, or by more agitated water action (the surface fossil remains are mostly unabraded). However, these processes were weaker in some protected conglomerate interstices, and are recorded only as an interruption in sedimentation with an indistinctly washed-out surface. The following change of environment, i.e., new sea level rise, seems to have been long term. The diabase clasts (most striking are the boulders) with altered (corroded) surfaces, were transported into the channel from the newly flooded shore zone, where they were previously exposed and corroded in the spray zone of the sea. tected conglomerate interstices. A varying sedimentation rate may be postulated (see e.g., Delamette 1990), with the most intensive sediment input occurring in the zone of columnar (colloformic) growths. The repetitive light limestone and greenish claystone laminae show relatively
Stromatolitic build-ups gradually formed in the pro- 


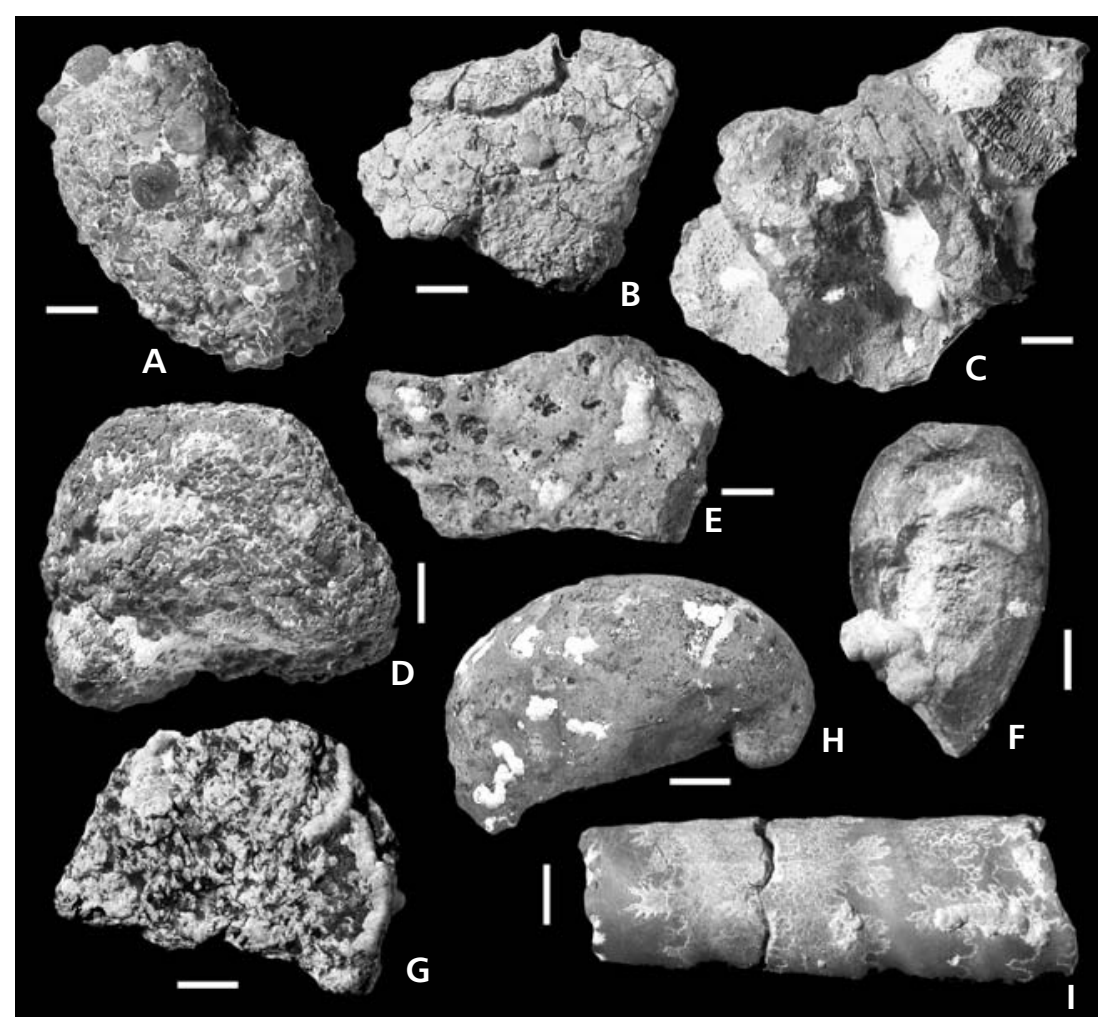

Figure 21. Chrtníky. • A-F, H, I - phosphatic intraclasts from clayey limestone of unit 7. • G small diabase clast. All intraclasts are colonized by the foraminifer Acruliammina longa. $\bullet$ I - fragment of cast of Sciponoceras gracile, dating the intraclasts to the oldest Late Cretaceous sedimentary episode in the Chrtníky area (Late Cenomanian, see the text). Scale bars represent $2 \mathrm{~mm}$.

mats. The phosphatization of stromatolite top laminae also affected the laterally situated erosional surfaces, giving them the features of mineralized hardgrounds (here designated as hardgrounds $s$. lat.). The boulder surfaces were also coated by thin phosphatic crusts. The stromatolites seem to indicate a relatively shallow-water stagnation period, but the following phosphogenesis more probably reflects an accelerated transgression with deepening.

\section{Step 5. Sedimentation immediately above stromatolites and hardgrounds}

The dysoxic conditions of the bottom phosphogenic processes in the area of GC, and the exposure of the stromatolites (indicated by very rare encrusters; see above), ended with the revived input of calcareous muds, probably winnowed from other nearby sedimentary areas. This would have caused a type of sedimentation resembling the limestone of the stromatolite laminae. The transport of macrofauna (mainly bra-

calm conditions with rhythmical growth of algal (?) and microbial coatings, trapping the calcareous mud particles and terminating by coatings of clayey particles with green nontronite. The amount of pyrite in basal stromatolite parts, sometimes very striking, indicates anaerobic conditions, possibly during early diagenesis, and may signal an elevated amount of organic matter. Rare but relatively large bioclasts [mostly bivalve and crinoid (Cyathidium) fragments and skeletal ossicles] and small diabase clasts incorporated in laminae indicate that stromatolites formed within reach of sediment input from higher-energy sea zones, and larger bioclasts could occasionally penetrate the narrow canals of the interstices. No small encrusters of laminae were found within the stromatolites (see Martin-Algarra \& Vera 1994). The only encruster observed was a single specimen of a ?coralline sponge (Gen. et sp. indet.) cemented directly on the phosphatized topmost surface of a stromatolite build-up. On the erosional surfaces of the unprotected areas of the channel, only thin coatings of greenish claystone were formed, probably due to the current activity. No encrusters were found here. The stromatolite lamination became denser upwards. There occur various irregularities in the stromatolite fabric, probably caused by the disintegration and collapse of the algal chiopods) and small diabase clasts from the surroundings was, however, more intense. The hardgrounds ( $s$. lat.) in the more open areas were also gradually covered, but the sedimentation gradually decreased and a firmground formed.

\section{Step 6. Sedimentation of dark siltstones, burrowing}

The grey to black deposits possibly document the return of dysoxic conditions indicated by palynomorphs and a high degree of organic matter enrichment. The deposits of this lithology are preserved prevailingly as dark burrow fills in the firmground of step 5, and only in minute erosional relics on the surface thereof. The burrowed tunnels approached the hardground surfaces and the top parts of stromatolites. These are, however, never bioturbated, thus showing sufficient lithification. The subsequent erosion event $\left(\mathrm{e}_{3}\right.$ in Fig. 3B) was rather strong, especially in the more open bottom places where partial local exhumations of the underlying hardground are shown to have occurred. On the other hand, substantially weaker erosion is recorded in the protected interstices with stromatolites. 


\section{Step 7. Sedimentation accompanied by strongly diverse macrofaunal communities}

The above-mentioned erosion event $\left(\mathrm{e}_{3}\right)$ was accompanied or immediately followed by the deposition of organodetritic sediments with abundant faunal remains, among which bryozoans, sponges, and especially crinoid Cyathidium predominate. The environment was fully oxic. The primary occurrence of this sediment was, however, restricted to the more open areas of the bottom, where it formed local lense-like bodies. The transport accompanying this sedimentation was only local, so that the deep narrow interstices in (probably elevated) areas with densely piled boulders could not be penetrated. Abundant phosphatized casts of Late Cenomanian macrofauna and fragments of phosphatized sediment document destruction and redeposition from the still-surviving remains of the oldest Cretaceous (Cenomanian) deposits of the area, even though the Early Turonian age of these sediments is proved by a find of Inoceramus ex gr. labiatus. An unconformity against the overlying beds (unit 8) represents the only locally winnowed surface. The absence of the sediments of unit 7 throughout much of the area probably followed from their irregular primary distribution. The sedimentation of unit 7 probably forms an entity with the overlying sponge beds, as similar sediments are known even at other localities of Chrtníky type (compare, e.g., with Velim; Žitt et al. 1997). However, no erosion was found anywhere.

\section{Step 8. Environments with sponge communities}

It is necessary to re-emphasize that respective sediments (mainly those of bed a) penetrate deeply into the top parts of the conglomerate, and that even the sediments of bed $f$ (see below) still kept a position in the channel during their formation, though in the upper channel parts. The sedimentary cover of the adjacent seaward bottom parts outside the channel was probably so thick that the channel fills only formed small landward inlets. During the post-erosional sedimentation of bed a, at least two thin burrowed horizons demonstrate the repeated decrease in sedimentation rate and the formation of firmgrounds. The sediment is still relatively organic-rich, hard, and carbonate-rich, and rapidly passes upwards into the light-grey siltstone, indicating further rapid deepening of the sea. The bottoms of the beds a-e were generally muddy during sedimentation (today siltstones, claystones), on which only a limited range of taxa could survive. Although the immediately adjacent, steep, rocky sides of the channel and the surrounding elevated rocky areas could offer sufficient habitats for the survival of benthos, some environmental factors had to limit them. Rare individuals of faunal groups other than sponges in

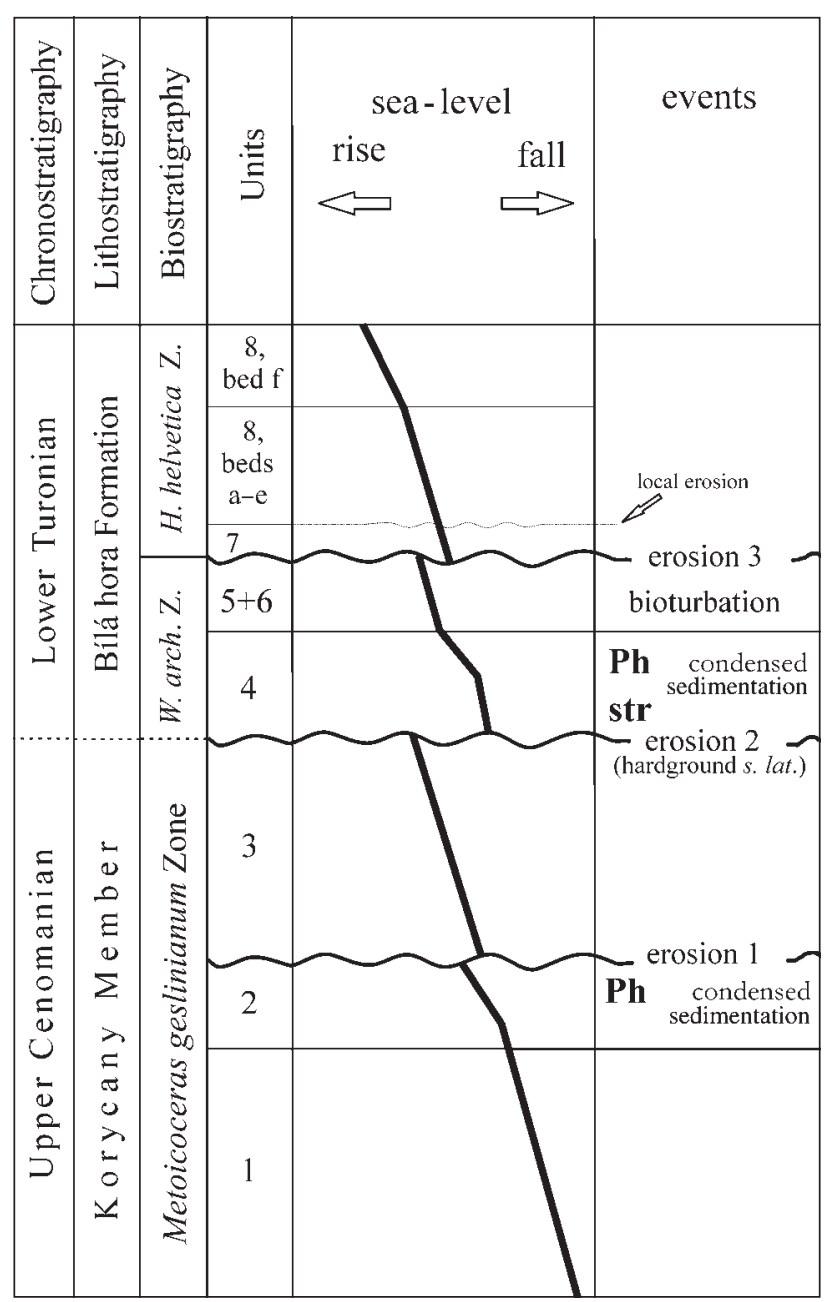

Figure 22. Sketch showing sea-level changes and major events in the Chrtníky area during the Late Cenomanian-Early Turonian (except the oldest Late Cenomanian cycle preserved only as intraclasts - see Fig. 21). $\mathbf{P h}$ - period of phosphogenesis, $\mathbf{s t r}$ - stromatolites.

these muddy deposits of otherwise high preservation potential probably correspond to their low presence in this environment. A partial depletion of oxygen may be postulated for this environment. The situation changed during the sedimentation of bed $\mathrm{f}$, when the bottom was probably more suitable for a bloom of diversified fauna. The taxonomic and morpho-functional composition of the sponge and bryozoan assemblages and taxonomy in associations of foraminifera and palynomorphs show a gradual deepening within step 8. Clastic input also gradually decreased.

Large corroded boulders, which mostly lie on intact, underlying boulders of the conglomerate (for their probable input see step 4), are rarely found "floating" in the relatively soft sediments of beds a-e of unit 8 . This peculiar condition could be caused by the occasional input of clasts from nearby areas during storms. A steep diabase elevation with corroded and encrusted surface, preserved about 150 metres from the channel, demonstrates the character of 
the bottom. Such rocks could supply boulders for a very long time, as their heights exceeded the base of bed $f$ of the GC by several metres. The new position of each deposited boulder is marked by the settling of slope-oriented cementing epifaunas (Žítt \& Nekvasilová 1994), while on the surrounding free rocky bottom it continued in its original unchanged orientation.

\section{Discussion and conclusions}

1. The present study of the Late Cretaceous sections at Chrtníky has resulted in much new information on the palaeontology, sedimentology, and palaeoenvironmental aspects of the deposition of the Korycany Member (PerucKorycany Formation) and the Bílá Hora Formation. The products of five sedimentation episodes were recorded as follows: the oldest sediments preserved only as intraclasts; sediments of units 1 and 2; sediments of unit 3, units 4-6, and units 7, 8. The three oldest episodes are of the Late Cenomanian age, and the two younger belong to the Lower Turonian.

2. The area of the Palaeozoic diabase massif at Chrtníky was topographically elevated during the first documented flooding by the Late Cenomanian sea. This massif, together with the surrounding areas, formed headland cliffs exposed to wave attacks (Trenhaile 1987, Clark \& Johnson 1995). The oldest reliably documented sediments of the area are not coarse clastics but a siltstone-sandstone complex containing phosphatic intraclasts with Sciponoceras gracile found redeposited in younger beds (the top of unit 3 , but mainly unit 7). The phosphogenesis related to this oldest sedimentation episode at Chrtníky may have been coeval with that at Předboj (central Bohemia), the latter being documented by phosphatic products that were redeposited during the boundary interval Rotalipora cushmani - Praeactinocamax plenus biozones (Žítt et al. 1999, Žítt \& Mikuláš in press). These oldest Chrtníky deposits, together with the subsequent phosphatization, may also be isochronous with the lower Metoicoceras geslinianum Zone, parasequence P1 of Uličný et al. (1996, 1997) distinguished at Pecínov, west of Prague.

It is interesting that these oldest sediments of offshore character were probably situated so high on the land that they could be reached and reworked as late as the transgression in which the top conglomerates (unit 3) formed, and again a little later (unit 7). It therefore seems possible that the area became uplifted after the deposition of these oldest Cenomanian sediments. Good intraclast preservation may indicate their easy release from deeply, subaerially weathered host sediments probably situated high on land.

3. The oldest in situ deposits (coarse clastics of unit 1) belong to the boundary interval of Rotalipora cushmani Praeactinocamax plenus, yielding a community contai- ning the brachiopod Gisilina? rudolphi and the echinoid Goniopygus menardi. Deposits of comparable age also occur at Předboj, Radim, and Velim (central Bohemia; see Žítt et al. 1997, 1999). The younger phase of conglomerate deposition (unit 3) is probably also of Late Cenomanian age (Rastellum carinatum), even though part of the taphocoenosis (e.g., Cyclothyris zahalkai) has been generally considered as Early Turonian. A more precise dating of these beds is not possible without further studies.

4. Two periods of condensed sedimentation and mineralization (accompanied by local omission of sedimentation) are recorded in the study area. It is important that even during these intervals there was an input of bioclasts, indicating not only the existence of coeval fully oxic environments in shallower sea zones, but also the important activity of water currents even in deeper dysoxic (or anoxic) environments in the area of sedimentary stagnation (phosphogenesis, stromatolites).

The older condensation interval (unit 2) was probably associated with accelerated transgression. A slightly fluctuating sea level first resulted in organic matter enrichment, and then in repeated phosphogenesis interrupted by temporally minor deposition of sediments. The erosion of the condensed deposits must have followed a brief period of lithification, as the new sediments caused their partial deformation. We therefore interpret the initiation of the new conglomerate deposition (unit 3 ) as a reflection of the new transgression pulse after a rapid, small-scale shallowing of the sea.

The younger condensation interval (unit 4) was more complex and followed on the erosion surface $\left(\mathrm{e}_{2}\right)$ forming the top of conglomerates of unit 3 . We tentatively assume that the beginning of this erosion coincides with the top of the M. geslinianum Zone of the Upper Cenomanian, i.e. with the top of parasequence P2 of Uličný et al. (1996, 1997) at Pecínov. However, the total thickness and the lithology of sediments removed are unknown, and the erosion may be much younger. The stratigraphic gap could encompass the upper part of the Late Cenomanian $M$. geslinianum and/or the total or part of Neocardioceras juddii zones. Nevertheless, some time was necessary for creating the pre-Turonian, extremely shallow-water conditions, and for the corrosion of the diabase rocky bottom, which was elevated only a few metres above the erosion surface. The clastics uncovered in nearby shallower areas were also corroded. Only at the beginning of a new and rapid sea level rise, and during the corresponding shift of the shoreline, could part of corroded boulders be redeposited into the Giant Channel, with the condensed sedimentation appearing later. While stromatolites were formed in the conglomerate interstices (the first find of this type in the Bohemian Cretaceous Basin), erosional surfaces in more open areas remained bare. We suggest that the lowered sedimentation rate indicated by the slow growth of 
stromatolites was characterised by long-term, periodically changing current actions and scouring, during which the carbonate erosion surfaces of more open bottom parts could also be further affected into the final form (hardgrounds sensu lato). The age of the stromatolites and the subsequent phosphogenesis is highly speculative, as no biostratigraphic data were collected for them. However, because the foraminifera of the overlying thin limestone (unit 5) probably belong to the lowest Turonian, and no discontinuity is apparent above or on the phosphatized stromatolite, this could also have been deposited in the earliest Turonian. The age of the immediately subsequent burrowing (oxygen depletion, unit 6) must be nearly the same. The condensed basal Turonian sedimentation with phosphates is well known throughout the basin (e.g., Čech et al. 1980, Valečka \& Skoček 1990, Uličný et al. 1996, 1997). During the Early Turonian erosion event $\left(\mathrm{e}_{3}\right)$, most of the black deposits and part of the underlying burrowed limestones were removed. This erosion could have partially exhume the older erosion surface $\left(\mathrm{e}_{2}\right.$; hardground s. lat.).

5. The subsequent sea level rise was accompanied by the onset of the Early Turonian sedimentation of the Helvetoglobotruncana helvetica Zone. The destruction of the remaining oldest sediments of the area (those with Sciponoceras) is well documented by phosphatic intraclasts transported into the oxic environment rich in macrofauna (unit 7). This sedimentation probably constitutes an entity with the overlying sponge beds (compare e.g., with Velim; Žitt et al. 1997), even though a slight erosion surface lies between them at Chrtníky. The silty to clayey sedimentation of the sponge beds, basally slightly enriched in Corg, with some thin burrowed firmground horizons and possible slight depletion in oxygen (deposits of unit 8), indicates a gradual deepening of the sea, which is well documented by the composition of the palynomorph, bryozoan, and sponge assemblages. Three depth-dependent types of sponge assemblages were distinguished:

a) the shallow-water Pachytilodia bohemica,

b) the intermediate Chonella-Verruculina-Siphonia, and

c) the relatively deepest water Laocoetis-Guettardiscyphia-Diplodictyon assemblages.

The distribution of bryozoans shows similar features (see Table 1).

6. Taphonomy supplied data which are consistent with the palaeoenvironmental development of the area. Units 7 and 8 (bed f) of the Lower Turonian are comparable in the majority of taphonomic features, the latter showing a higher degree of time averaging. The encrustation of bioclasts in the Early Turonian units 4-8 (bed f) shows similar features with prevailing small and rapidly growing opportunistic cosmopolitan forms (mainly foraminifera, worms, bryozoans, small oysters), and more rarely by larger octocorals and bivalves. In unit 8 , beds a-f, the en- crusting Atreta-Bdelloidina community is well documented on hard substrates in sediments (e.g., corroded clasts and sponges), and on the adjacent corroded rocky bottom elevation.

7. Remains of the crinoid Cythidium aff. depressum provided important material for studying taphonomy and bryozoan encrusters. Their occurrence is confined to the Early Turonian units 4, 5, and mainly 7 . The Cyathidium material collected at Chrtníky is enormously rich, representing one of the largest sets of specimens of the European Upper Cretaceous (hundreds of thecae and brachials).

8. Nontronite was identified in the BCB for the first time, and occurs only in the greenish clay coatings of the phosphate precipitates and stromatolite laminae that originated during condensation intervals. We preliminarily assume that intense weathering (see corrosion) of the diabases supplied the nontronite or its precursor materials. A more detailed study of this phenomenon is needed.

\section{Acknowledgements}

We thank S. Čech (Czech Geological Survey, Prague), M. Košták (Charles University, Prague), O. Nekvasilová (Prague), J.W.M. Jagt (Natuurhistorisch Museum Maastricht), and J. Adamovič (Institute of Geology, ASCR, Prague) for their assistance with some faunal identifications and improvement of the manuscript. We are obliged also to J. Ulrych, J. Novák, J. Dobrovolný, and M. Vavrdová (Institute of Geology ASCR, Prague) for help with mineralogical determinations and the supply of stromatolite literature. P. Samek, the chief manager of the Chrtníky quarry, is acknowledged for his understanding and support for our field work. The geological and palaeontological research was undertaken within project Z 30130516 of the Institute of Geology ASCR, Prague. The Bryozoa research has been supported by the projects RK04P03OMG008 and MK00002327201 of Ministry of Culture of the Czech Republic.

\section{References}

BRETT, C.E. \& BAIRD, G.C. 1986. Comparative taphonomy: a key to paleoenvironmental interpretation based on fossil preservation. Palaios 1, 207-227.

ClARK, H.C. \& JOHNSON, M.E. 1995. Coastal geomorphology of andesite from the Cretaceous Alisitos Formation in Baja California (Mexico). Journal of Coastal Research 11(2), 401-414.

ČECH, S., Klein, V., Kříž, J. \& VALEČKA, J. 1980. Revision of the Upper Cretaceous stratigraphy of the Bohemian Cretaceous Basin. Věstník Ústředního ústavu geologického 55(5), 277-296.

Delamette, M. 1990. Aptian, Albian and Cenomanian microbialites from the condensed phosphatic deposits of the Helvetic shelf, Western Alps. Eclogae geologicae Helvetiae 83(1), 99-121.

HercogovÁ, J. 1978. Zástupci rodů Frondicularia, Palmula $a$ 
Neoflabellina $v$ křídě Českého masívu. MS, archiv Ústředního ústavu geologického. Praha.

HRADECKÁ, L. 1996. Gavelinella Brotzen, 1942 and Lingulogavelinella Malapris, 1969 (Foraminifera) from the Bohemian Cretaceous Basin. Sborník geologických věd, Paleontologie 33, 79-96.

KNIGHT-JONES, E.W. 1951. Gregariousness and some other aspects of the settling behaviour of Spirorbis. Journal of the Marine Biological Association of the United Kingdom 30, 201-222.

KrautTer, M. 1997. Aspekte zur Paläökologie postpaläozoischer Kieselschwämme. Profil 11, 199-324.

Martin-Algarra, A. \& Vera, J.A. 1994. Mesozoic pelagic phosphate stromatolites from the Penibetic (Betic cordillera, southern Spain), 345-391. In BERTRAND-SARFATI, J. \& Monty, C. (eds) Phanerozoic Stromatolites II. Kluwer Academic Publishers, Dordrecht.

MCKINNEY, F.K. \& JACKSON, J.B.C. 1989. Bryozoan Evolution, 238 pp. Unwin Hyman, London.

MonTy, C. \& MAS, J.R. 1981. Lower Cretaceous (Wealdian) blue-green algal deposits of the province of Valencia, Eastern Spain, 85-120. In MonTY, C. (ed.) Phanerozoic stromatolites. Springer Verlag, Berlin.

NeKVASILOVÁ, O. 1973. The brachiopod genus Bohemirhynchia gen. n. and Cyclothyris McCoy (Rhynchonellidae) from the Upper Cretaceous of Bohemia. Sborník geologických věd, Paleontologie 15, 75-117.

NeKVASILOVÁ, O. 1975. The etching traces produced by pedicles of Upper Cretaceous brachiopods from Bohemia (Czechoslovakia). Časopis pro mineralogii a geologii 28(1), 23-30.

NeKVASILOVÁ, O. 1986. Rozšîření svrchnokřídových ramenonožců (Brachiopoda) na chráněných paleontologických lokalitách Středočeského kraje. Bohemia centralis 15, 7-14.

NeumanN, C. 2000. Evidence of predation on Cretaceous sea stars from north-west Germany. Lethaia 33, 65-70.

RoBASZYNSKI, F. \& CARON, M. 1995. Foraminifères planctoniques du Crétacé commentaire de la zonation Europe Méditerranée. Bulletin de la Société géologique de France 166(6), 681-692.

TichÝ, V. 1968. Geologie a hydrogeologie svrchní křídy severovýchodně Železných hor v širším okoli Heřmanova Městce mezi Cholticemi a Chrudimí. MS, diploma thesis. PřF UK, Praha.

TREnHAILE, A.S. 1987. The geomorphology of rock coasts. 373 pp. Clarendon Press, Oxford.

UliČnÝ, D., ČECH, S., HRAdECKÁ, L., HLAdíkOVÁ, J. \& LAURin, J. 1996. Pecínov quarry: the record of mid-Cenomanian through early Turonian sea-level changes and related events, Part 2: Sea-level changes and geochemical anomalies across the Cenomanian-Turonian boundary, 17-23. In $\breve{C E C H}_{\mathrm{EC}}$ S. et al. Stratigraphy and facies of the Bohemian-Saxonian Cretaceous Basin. Guide to field trip B1. Fifth International Cretaceous Symposium and Second Workshop on Inoceramids, Freiberg, Germany, September 1996.

UličnÝ, D., HladíkOVÁ, J., ATtReP, M.J., ČECH, S., HRADECKÁ, L. \& SvobodovÁ, M. 1997. Sea-level changes ang geochemical anomalies across the Cenomanian-Turonian boundary: Pecínov quarry, Bohemia. Palaeogeography, Palaeoclimatology, Palaeoecology 132, 265-285.

VALEČKA, J. \& SKOČEK, V. 1990. Litoeventy v české křídové pánvi. Věstník Ústředního ústavu geologického 65(1), 13-28.
VlačIHA, V. 2002. Macrofaunal taphocoenoses of the Peruc-Korycany and Bílá hora Formations at Chrtníky near Přelouč (Bohemian Cretaceous Basin). Acta Universitatis Purkynianae, Studia Biologica 6, 1-8.

VodrÁŽKA, R. 2005. Rod Hillendia Reid, 1964 a Guettardiscyphia Fromental, 1860 (Porifera, Hexactinellida) z české křidové pánve. MS, diploma thesis. PřF UK, Praha.

ZÁGORŠEK, K. 1996. Palaeoecology of the Eocene bryozoan marl in the Alpine-Carpathian Region, 413-422. In GORDON, D.P., Smith, A.M. \& Grant-MackiE, J.A. (eds) Bryozoans in space and time. Wellington.

ZÁrubA, B. 1965a. Beitrag zur Kenntnis der Art Exogyra sigmoidea Reuss, 1844 (Ostreidae) aus der Brandungsfazies der böhmischen Kreideformation. Sborník Národního muzea v Praze, ̌̆ada B - př́rodní vědy 21(1), 11-37.

ZÁRUBA, B. 1965b. Nový výskyt druhu Exogyra reticulata Reuss v mořském cenomanu svrchní křídy. Časopis Národního muzea, Oddíl přirodovědný 134, 151-152.

ZÁzvORKA, V. 1946. Transgrese svrchní křídy v severozápadní části Železných hor. Věstník Královské české společnosti nauk, Tř́lda matematicko-př́rodovědecká 1944, 1-26.

ZIEGLER, V. 1984. Family Serpulidae (Polychaeta, Sedentaria) from the Bohemian Cretaceous Basin. Sborník Národního muzea v Praze, Řada B - prírodní vědy 39(4), 213-252.

ŽítT, J. 2004. Asteroidea in Late Cretaceous taphocoenoses of Bohemia, Czech Republic, 509-512. In Heinzeller, T. \& NeBElsick, J.H. (eds) Echinoderms: München, Proceedings of the $11^{\text {th }}$ International Echinoderm Conference, Munich, Germany. A.A. Balkema Publishers, Amsterdam.

ŽíTT, J. 2005. The asteroid genus Haccourtaster (Echinodermata, Goniasteridae) in the Bohemian Cretaceous Basin, Czech Republic. Cretaceous Research 26, 225-237.

ŽítT, J., BosÁK, P., HradeCKÁ, L. \& SvobodovÁ, M. 2001. Late Cenomanian-Early Turonian hardgrounds and nearshore depositional environments (Bohemian Cretaceous Basin). In Ferré, B., Fouray, M. \& TABouelle, J. (eds) Colloquium on the Cenomanian Stage 2001, Oct. 19-22, 2001, Rouen, France. Bulletin de la Société d'Étude des Sciences Naturelles d'Elbeuf 2001, 105-107.

ŽítT, J., Kopáčová, M., Nekovařík, Č. \& PeZA, L.H. 2002 b. New data on the Late Cenomanian taphocoenose at Kuchyňka near Brázdim (Bohemian Cretaceous Basin). Journal of the Czech Geological Society 47, 55-64.

ŽítT, J. \& MikULÁš, R. in press. Substrate of bivalve borers as recorded on phosphatic fills of Gastrochaenolites; palaeoenvironmental context (Bohemian Cretaceous Basin). Ichnos.

ŽítT, J. \& NeKVASILOVÁ, O. 1991. Epibionti přicementovaní k diabasovým klastům a skalnímu dnu ve svrchní křídě Železných hor a okolí. Časopis Národního muzea, řada př́rodovědná 1987, 156(1/4), 17-35.

ŽítT, J. \& NeKVASILOVÁ, O. 1994. Orientation of Spondylus valves cemented to the hard-rock substrates (Bivalvia, Upper Cretaceous Bohemia). Journal of the Czech Geological Society 39(4), 281-295.

ŽítT, J. \& NEKVASILOVÁ, O. 1996. Epibionts, their hard-rock substrates, and phosphogenesis during the Cenomanian-Turonian boundary interval (Bohemian Cretaceous Basin). Cretaceous Research 17, 715-739. 
Žítt, J., Nekvasilová, O., Bosák, P., Svobodová, M., ŠTEMPROKOVÁ-JírOVÁ, D. \& ŠŤASTNÝ, M. 1997. Rocky coast facies of the Cenomanian-Turonian Boundary interval at Velim (Bohemian Cretaceous Basin, Czech Republic). First part. Bulletin of the Czech Geological Survey 72(1), 83-102. Second part. Ditto 72(2), 141-155.

Žítt, J., Nekvasilová, O. \& HradeckÁ, L. 2002a. Platidiid brachiopods from the Middle Turonian of the Bohemian Cretaceous Basin (Czech Republic). Paläontologische Zeitschrift 76(2), 251-255.
Žítt, J., Nekvasilová, O., Hradecká, L., Svobodová, M. \& ZÁrubA, B. 1999. Rocky coast facies of the Unhošti-Tursko High (late Cenomanian-early Turonian, Bohemian Cretaceous Basin). Sborník Národního muzea v Praze, Řada B - přírodní vědy 54(3-4), 79-116.

ŽítT, J., Svobodová, M. \& VodRÁžKA, R. 2004. Příbřežní zóna českého křídového moře při hranici cenoman/turon; příklady vývoje tafocenóz a sedimentačního prostředí, 117-118. In ZLINSKÁ, A. (ed.) 5. paleontologická konferencia, zborník abstraktov. Bratislava. 